\title{
Maternal antenatal multiple micronutrient supplementation for long-term health benefits in children: a systematic review and meta-analysis
}

Delan Devakumar ${ }^{1 *}$, Caroline H. D. Fall², Harshpal Singh Sachdev³ ${ }^{3}$ Barrie M. Margetts ${ }^{4}$, Clive Osmond ${ }^{2}$, Jonathan C. K. Wells ${ }^{5}$, Anthony Costello ${ }^{1}$ and David Osrin ${ }^{1}$

\begin{abstract}
Background: Multiple micronutrient supplementation for pregnant women reduces low birth weight and has been recommended in low- and middle-income countries (LMICS) to improve child survival, growth and health. We aimed to review the evidence from long-term follow-up studies of multiple micronutrient supplementation beginning in the later first or second trimester.

Methods: We searched systematically for follow-up reports from all trials in a 2015 Cochrane review of multiple micronutrient supplementation in pregnancy. The intervention comprised three or more micronutrients and the comparison group received iron $(60 \mathrm{mg})$ and folic acid $(400 \mu \mathrm{g})$, where possible. Median gestation of commencement varied from 9 to 23 weeks. Primary outcomes were offspring mortality, height, weight and head circumference, presented as unadjusted differences in means or proportions (intervention minus control). Secondary outcomes included other anthropometry, body composition, blood pressure, and cognitive and lung function.

Results: We found 20 follow-up reports from nine trials (including 88,057 women recruited), six of which used the UNIMMAP supplement designed to provide recommended daily allowances. The age of follow-up ranged from 0 to 9 years. Data for mortality estimates were available from all trials. Meta-analysis showed no difference in mortality (risk difference -0.05 per 1000 livebirths; $95 \% \mathrm{Cl},-5.25$ to 5.15). Six trials investigated anthropometry and found no difference at follow-up in weight-for-age $z$ score $(0.02 ; 95 \% \mathrm{Cl},-0.03$ to 0.07$)$, height-for-age $z$ score $(0.01$; $95 \% \mathrm{Cl},-0.04$ to 0.06$)$, or head circumference $(0.11 \mathrm{~cm} ; 95 \% \mathrm{Cl},-0.03$ to 0.26$)$. No differences were seen in body composition, blood pressure, or respiratory outcomes. No consistent differences were seen in cognitive function scores. Conclusions: There is currently no evidence that, compared with iron and folic acid supplementation, routine maternal antenatal multiple micronutrient supplementation improves childhood survival, growth, body composition, blood pressure, respiratory or cognitive outcomes.
\end{abstract}

Keywords: Child, Micronutrients, Prenatal exposure delayed effects

\footnotetext{
* Correspondence: d.devakumar@ucl.ac.uk

'Institute for Global Health, University College London, 30 Guilford St,

London, UK

Full list of author information is available at the end of the article
} 


\section{Background}

Micronutrient deficiency is believed to affect approximately two billion people worldwide, with pregnant women being at particular risk because of their high metabolic demands [1]. The World Health Organization (WHO) considers micronutrient deficiency to be of particular concern in low-income countries, where women's diets are likely to be deficient in both quantity and quality. The importance of micronutrients is becoming increasingly apparent, especially in resource-poor settings in which women may enter pregnancy with multiple micronutrient (MMN) deficiencies [2-4]. For example, $38 \%$ of pregnant women have iron deficiency leading to anaemia [5] and $15 \%$ have vitamin A deficiency causing night blindness and increasing the risk of infection $[6,7]$. Impaired antenatal nutrition can affect fetal development and growth in the short term, subsequent growth and cognitive development in the medium term, and risk of chronic disease in the longer term [3]. There is good evidence that folic acid in pregnancy reduces neural tube defects and the mortality arising from them $[8,9]$. While the evidence base is not substantial for iron and folic acid, a Cochrane review described a mean increase in birthweight of $57.7 \mathrm{~g}$ (95\% CI, 7.7-107.8 g) [10].

While there is evidence that MMN supplementation reduces the prevalence of small for gestational age (SGA) births [11], the primary rationale for recent recommendations to implement routine MMN supplementation for pregnant women in developing countries is that such birth weight increments will lead to reductions in childhood stunting and mortality $[12,13]$. In addition to the immediate effects on health, growth in early childhood is important because of its association with adult health and human capital [14]. The hypothesis of the developmental origins of health and disease proposes critical or sensitive periods in early development in which environmental influences can have lasting effects on growth and physiology [15]. In humans, these critical periods are thought to occur predominantly in prenatal life and extend into early childhood. Suggested mechanisms include an interplay between environment (including maternal nutritional status), genes, and hormones, in which epigenetic regulation plays a part $[3,15,16]$. Evidence for the hypothesis comes mainly from observational studies showing associations between low birthweight and adverse adult health outcomes [17], from historical events such as the Dutch Hunger Winter [18], and from animal studies [19]. Long-term follow-up of children born during trials of maternal MMN supplementation offer a potentially stronger test of the hypothesis. If MMN supplements are to be recommended for pregnant women, it is important to know whether they lead to the sustained improvements in child health predicted by an increase in birthweight. In this review, we searched for reports that followed up the trials included in the 2015 Cochrane review
[20], focusing on childhood mortality and health-related outcomes (growth, body composition, cardio-metabolic risk markers, cognition, lung function). We hypothesized that, compared with iron and folic acid, antenatal MMN supplementation would lead to longer-term improvements in health and survival.

\section{Methods \\ Eligibility criteria \\ Types of report}

We attempted to find all reports of follow-up of children born in the individual or cluster randomized controlled trials included in the 2015 Cochrane review. The review included 17 trials and excluded 97. The main reasons for exclusion were not meeting intervention and comparison group criteria, not assessing supplementation in a healthy population, and providing supplementation within food fortification initiatives [20].

\section{Participants}

Participants were children born in the trials in the 2015 Cochrane review [20] who had been subsequently followed up.

\section{Intervention and comparison groups}

The intervention group included women who had received multiple micronutrient supplements, defined as "containing three or more micronutrients" in pregnancy [20]. All intervention groups received iron and folic acid. For consistency, the comparison group chosen a priori was iron $60 \mathrm{mg}$ and folic acid $400 \mu \mathrm{g}$, where possible, as this regimen is generally recommended for pregnant women [21]. We planned to consider all trials together, with the possibility of subgroup examination when supplementation regimens differed. Trials with cointerventions (for example, food supplements) were eligible provided that the co-intervention was similar in both allocation arms. If a second randomization was conducted after birth, we did not include arms that received MMN supplements in the comparison group.

\section{Outcome measures}

The primary outcomes were mortality (difference per 1000 livebirths), height and weight (as continuous WHO $z$ scores, adjusted for age and sex), and head circumference (continuous difference), presented as unadjusted differences (intervention minus control). At a population level, risk differences may be more interpretable than odds ratios because they give a clearer impression of the effects of an intervention in terms of potential policy. When not reported, we calculated mean differences with $95 \%$ confidence intervals. Mortality difference was either as described in the trial paper or follow-up report, or calculated from available trial profiles. Secondary outcomes 
included categorical proportions of stunting $(<-2 z$ scores height-for-age), underweight $(<-2 z$ scores weight-forage), wasting ( $<-2 z$ scores weight-for-height) and low body mass index (BMI) $(<-2 z$ scores BMI-for-age), descriptions of body composition (lean and fat mass, skinfold thickness), blood pressure, cognitive tests, and lung function. Cognitive and motor development were as assessed by trialists, including use of indexes such as the Bayley Mental Development Index, Bayley Psychomotor Development Index, Stanford-Binet Test, DENVER II Developmental Screening Test and Wechsler Intelligence Scale for Children. Effect modification by maternal nutritional status and child sex was reported when available. Birth outcomes were not considered as they had been reported previously $[11,22]$.

\section{Search strategy and study selection}

We searched PubMed, Web of Science and the Global Health Library for articles that included trial lead author names, location, trial number, or the given trial name (Additional file 1: Text S1). We contacted trial authors when eligibility was unclear and used a snowballing approach, searching citation lists and 'related articles'. Study titles and abstracts were screened for eligibility by DD and JCKW independently. Differences were resolved by discussion. Full papers were obtained for potentially eligible citations. The results were assessed for multiple publications and one study was excluded. We did not assess reports of maternal outcomes. No exclusions were applied for age, dates of coverage, or language.

\section{Data extraction and analysis}

Publications from each trial were examined by two review authors (unconnected with the trial) independently (AC, BM, CHDF, DD, DO, HSS, and JCKW), using a pre-tested data extraction form. Differences were resolved by discussion. We contacted trial authors for clarifications and consolidated multiple reports from the same trial using data from the later follow-up. We used anthropometric $z$ scores adjusted for age and sex (WHO reference ranges). Meta-analyses were conducted if sufficient reports were available, using the DerSimonian and Laird model. When numbers of deaths were provided for a subgroup of participants in a second age interval, we combined the data to produce an estimate of the mortality rate across both intervals using standard life-table techniques, and generated $95 \%$ confidence intervals through a simulation approach. Outcome measures were risk differences per 1000 livebirths (mortality), differences in anthropometry $z$ scores (height-for-age (HAZ) and weightfor-age (WAZ)) and absolute values (head circumference and blood pressure). We assessed heterogeneity using the $\mathrm{I}^{2}$ statistic. In view of anticipated contextual heterogeneity, we used a random effects model for all meta-analyses.
Missing data were reported under attrition bias, but no further analyses were conducted. For cluster-randomised trials, we used reported cluster-adjusted estimates, irrespective of the method employed. If the analyses had not been adjusted for cluster design effect, we used a previously reported design effect from the trial paper to inflate the variance. Analysis was conducted in Stata, version 12 (StataCorp, College Station, TX, USA).

\section{Risk of bias}

Risk of bias for each study was assessed by two review authors (unconnected with the trial) independently (AC, BM, CHDF, DD, DO, HSS, and JCKW), using a pre-tested data extraction form. Differences were resolved by discussion and trial authors were contacted for clarifications. We used the same categorisation of bias of individual trials as in the Cochrane review 2015. We reported on bias in follow-up reports in the following categories: selection, attrition, reporting, performance and detection. We evaluated reporting bias by inspection of funnel plots for the primary outcomes of mortality, weight-for-age, height-for-age and head circumference.

\section{Sub-group analysis}

We performed sub-group analyses including trials that used UNIMMAP only and trials with different iron dosage ( $\sim 30$ or $60 \mathrm{mg})$ in control groups. Sensitivity analyses were not conducted.

\section{Results}

\section{Description of trials with follow-up reports}

Follow-up reports were identified for nine of the trials in the Cochrane review. In total, 88,057 women were recruited. The trials were spread geographically: two in Africa [23, 24], one in the Americas [25], and six in Asia [26-31]. All sites were rural, with the exception of Nepal Janakpur (urban and rural) and Guinea (semi-urban). Mean ages of mothers were similar and ranged from 21.5 (Nepal Janakpur) to 25.6 years (Indonesia). Mean maternal BMI, measured at recruitment during pregnancy, ranged from $19.3 \mathrm{~kg} / \mathrm{m}^{2}$ (Nepal Sarlahi) to $24.1 \mathrm{~kg} / \mathrm{m}^{2}$ (Mexico). Trial characteristics, with results summarized in the way in which they were presented in the trial papers, are shown in Table 1 and have been previously described in detail $[20,32]$.

Six of the nine trials used the UNIMMAP supplement developed by UNICEF, the United Nations University, and $\mathrm{WHO}$, and were designed to provide the recommended daily allowances. It contained vitamin A $800 \mu \mathrm{g}$, thiamine $1.4 \mathrm{mg}$, riboflavin $1.4 \mathrm{mg}$, niacin $18 \mathrm{mg}$, vitamin B6 $1.9 \mathrm{mg}$, folic acid $400 \mu \mathrm{g}$, vitamin B12 $2.6 \mu \mathrm{g}$, vitamin C $70 \mathrm{mg}$, vitamin D $5 \mu \mathrm{g}$, vitamin E $10 \mathrm{mg}$, copper $2 \mathrm{mg}$, iodine $150 \mu \mathrm{g}$, iron $30 \mathrm{mg}$, selenium $65 \mu \mathrm{g}$, and zinc $15 \mathrm{mg}$ [33]. The Bangladesh JiVitA trial used the same 
Table 1 Description of trials with follow-up reports

\begin{tabular}{|c|c|c|c|c|c|c|c|c|}
\hline Location & Trial & $\begin{array}{l}\text { Randomisation } \\
\text { scheme }\end{array}$ & $\begin{array}{l}\text { Pregnant women } \\
\text { allocated (MMN and } \\
\text { Fe60 Fol groups only) }\end{array}$ & $\begin{array}{l}\text { Mean duration from } \\
\text { LMP to beginning of } \\
\text { supplementation and } \\
\text { when supplementation } \\
\text { stopped }^{\mathrm{a}}\end{array}$ & Control content & Intervention content ${ }^{b}$ & $\begin{array}{l}\text { Mean maternal BMl } \\
\left(\mathrm{kg} / \mathrm{m}^{2}\right)\end{array}$ & $\begin{array}{l}\text { Main results from original trial } \\
\text { paper (intervention effect } \\
\text { relative to comparison group) }\end{array}$ \\
\hline $\begin{array}{l}\text { Bangladesh } \\
\text { JiVitA }\end{array}$ & West et al. [26] & Cluster & $\begin{array}{l}127,282 \text { women } \\
\text { under pregnancy } \\
\text { surveillance; } 44,567 \\
\text { pregnancies recruited } \\
\text { in } 596 \text { clusters }\end{array}$ & $\begin{array}{l}\text { Median at enrolment } \\
9 \text { weeks until } 12 \text { weeks } \\
\text { after birth }\end{array}$ & $\begin{array}{l}\text { Iron } 27 \mathrm{mg} \text {, folic } \\
\text { acid } 600 \mathrm{\mu g}\end{array}$ & $\begin{array}{l}\text { Vit } A \text {, thiamine, } \\
\text { riboflavin, vit } B_{3} \text {, vit } B_{6} \text {, } \\
\text { folic acid, } B_{12} \text {, vit } C \text {, } \\
\text { vit } D \text {, vit } E \text {, copper, } \\
\text { iodine, iron, selenium, } \\
\text { zinc }\end{array}$ & $\begin{array}{l}\text { Mean BMI unknown; } \\
\text { proportion < } 18.540 \%\end{array}$ & $\begin{array}{l}\text { Birthweight, + } 54 \text { g (95 \% Cl, } \\
41-66 \text { g) } \\
\text { SGA RR, } 0.98 \text { ( } 95 \% \text { Cl, } \\
0.96-1.01) \\
\text { Gestation, } 0.30 \text { weeks ( } 95 \% \mathrm{Cl} \text {, } \\
0.21-0.40 \text { weeks) } \\
\text { Neonatal mortality RR, } 0.98 \\
(95 \% \mathrm{Cl}, 0.88-1.20)\end{array}$ \\
\hline $\begin{array}{l}\text { Bangladesh } \\
\text { MINIMat }\end{array}$ & $\begin{array}{l}\text { Persson } \\
\text { et al. [27] }\end{array}$ & Individual & 1478 & 102 days until birth & $\begin{array}{l}\text { Iron } 60 \mathrm{mg} \text {, folic } \\
\text { acid } 400 \mu \mathrm{g} \text { and } \\
\text { "usual" food } \\
\text { supplementation }\end{array}$ & $\begin{array}{l}\text { UNIMMAP and "usual" } \\
\text { food supplementation }\end{array}$ & 20.3 & $\begin{array}{l}\text { Birthweight in MMN, } 2710 \mathrm{~g} \\
(95 \% \mathrm{Cl}, 2675-2745 \mathrm{~g}) \\
\text { Birthweight in control, } 2665 \mathrm{~g} \\
\text { ( } 95 \% \mathrm{Cl}, 2631-2699 \mathrm{~g}) \\
\text { Gestation in MMN, } 39.1 \text { weeks } \\
\text { ( } 95 \% \mathrm{Cl}, 38.9-39.3 \text { weeks); } \\
\text { gestation in control, } 38.8 \text { weeks } \\
\text { ( } 95 \% \mathrm{Cl}, 38.6-39.0 \text { weeks) } \\
\text { Perinatal mortality RR, } 0.95 \\
\text { (95\% Cl, 0.59-1.5) } \\
\text { Neonatal mortality RR, } 1.1 \\
\text { (95\% Cl, 0.64-2.0) }\end{array}$ \\
\hline Burkina Faso & $\begin{array}{l}\text { Roberfroid } \\
\text { et al. [23] }\end{array}$ & Individual & 1428 & $\begin{array}{l}125 \text { days until } \\
3 \text { months after birth }\end{array}$ & $\begin{array}{l}\text { Iron } 60 \mathrm{mg} \text {, folic } \\
\text { acid } 400 \mu \mathrm{g}\end{array}$ & $\begin{array}{l}\text { UNIMMAP; also } \\
\text { randomly assigned to } \\
\text { receive either } \\
\text { chloroquine } 300 \mathrm{mg} \\
\text { weekly or sulfadoxine } \\
1500 \mathrm{mg} \text { and } \\
\text { pyrimethamine } 75 \mathrm{mg} \\
\text { once in } 2 \text { nd and 3rd } \\
\text { trimesters as malaria } \\
\text { chemoprophylaxis }\end{array}$ & 20.9 & $\begin{array}{l}\text { Birthweight, }+41 \mathrm{~g} \mathrm{(} 95 \% \mathrm{Cl} \text {, } \\
-11 \text { to } 94 \mathrm{~g}) \text {, adjusted for } \\
\text { malaria prevention and health } \\
\text { centre } \\
\text { SGA, } 0.83 \text { ( } 95 \% \mathrm{Cl}, 0.65-1.07) \text {, } \\
\text { adjusted for malaria prevention } \\
\text { and health centre } \\
\text { Gestation, }-0.04 \text { weeks }(95 \% \mathrm{Cl} \text {, } \\
\text {-0.38 to } 0.29 \text { weeks), adjusted } \\
\text { for malaria prevention and } \\
\text { health centre } \\
\text { Perinatal mortality OR, } 1.78 \\
\text { (95\% Cl, 0.95-3.32) } \\
\text { Neonatal mortality OR, } 2.1 \\
\text { (95\% Cl, 0.78-5.64) }\end{array}$ \\
\hline China & Zeng et al. [28] & Cluster & $\begin{array}{l}3811 \text { women in } \\
104 \text { clusters }\end{array}$ & 96 days until birth & $\begin{array}{l}\text { Iron } 60 \mathrm{mg} \text {, folic } \\
\text { acid } 400 \mu \mathrm{g}\end{array}$ & UNIMMAP & 20.9 & $\begin{array}{l}\text { Birthweight in MMN, } 3198 \mathrm{~g} ; \\
\text { birthweight in control, } 3174 \mathrm{~g} \\
\text { SGA in MMN, } 16.9 \% \text {; SGA in } \\
\text { control, } 18.9 \% \\
\text { Gestation in MMN, } 39.8 \text { weeks; } \\
\text { gestation in control, } 39.8 \text { weeks } \\
\text { PMR in MMN group, 50.9; PMR } \\
\text { in control group, 36.9 } \\
\text { NMR in MMN group, 12.4; } \\
\text { NMR in control group, } 10.7\end{array}$ \\
\hline
\end{tabular}


Table 1 Description of trials with follow-up reports (Continued)

\begin{tabular}{|c|c|c|c|c|c|c|c|c|}
\hline Guinea Bissau & $\begin{array}{l}\text { Kaestel } \\
\text { et al. [24] }\end{array}$ & Individual & 1403 & 158 days until birth & $\begin{array}{l}\text { Iron } 60 \mathrm{mg} \text {, folic } \\
\text { acid } 400 \mu \mathrm{g}\end{array}$ & $\begin{array}{l}\text { UNIMMAP; if } \\
\text { haemoglobin } \\
\text { concentration < } 70 \\
\text { g/L, given additional } \\
\text { iron } 60 \mathrm{mg} \text { daily; all } \\
\text { women received } \\
\text { insecticide-treated } \\
\text { bednets, weekly anti } \\
\text { malarial prophylaxis } \\
\text { and malaria treatment } \\
\text { if needed }\end{array}$ & 23.3 & $\begin{array}{l}\text { Birthweight, }+53.0 \mathrm{~g}(95 \% \mathrm{Cl} \text {, } \\
-19 \text { to } 125 \mathrm{~g}) \\
\text { Perinatal mortality OR, } 0.82 \\
(95 \% \mathrm{Cl}, 0.53-1.26) \\
\text { Neonatal mortality OR, } 1.18 \\
(95 \% \mathrm{Cl}, 0.66-2.11)\end{array}$ \\
\hline Indonesia & $\begin{array}{l}\text { Shankar } \\
\text { et al. [29] }\end{array}$ & Cluster & $\begin{array}{l}31,290 \text { women, } 262 \\
\text { randomly assigned } \\
\text { midwives }\end{array}$ & $\begin{array}{l}146 \text { days until } 90 \text { days } \\
\text { after birth }\end{array}$ & $\begin{array}{l}\text { Iron } 30 \mathrm{mg} \text {, folic } \\
\text { acid } 400 \mu \mathrm{g}\end{array}$ & UNIMMAP & Not recorded & $\begin{array}{l}\text { Birthweight, }+21 \mathrm{~g}(95 \% \mathrm{Cl} \text {, } \\
-11 \text { to } 53 \mathrm{~g}) \\
\text { Perinatal mortality RR, } 0.90 \\
(95 \% \mathrm{Cl}, 0.79-1.03) \\
\text { Neonatal mortality RR, } 0.90 \\
(95 \% \mathrm{Cl}, 0.76-1.06)\end{array}$ \\
\hline Mexico & $\begin{array}{l}\text { Ramakrishnan } \\
\text { et al. [25] }\end{array}$ & Individual & $\begin{array}{l}873 \text { children born } \\
\text { in the trial were } \\
\text { subsequently } \\
\text { randomised to } \\
\text { receive postnatal } \\
\text { multiple } \\
\text { micronutrients or } \\
\text { iron and vitamin A } \\
\text { supplements }\end{array}$ & 69 days until birth & $\begin{array}{l}\text { Iron } 60 \text { mg; no } \\
\text { supplements on } \\
\text { Sundays }\end{array}$ & $\begin{array}{l}\text { Vit } A \text {, thiamine, } \\
\text { riboflavin, niacin, vit } B_{6} \text {, } \\
\text { folic acid, vit } B_{12} \text {, vit } C_{\text {, }} \\
\text { vit } D 3 \text {, vit } \mathrm{E} \text {, iron, } \\
\text { magnesium, zinc; no } \\
\text { supplements taken on } \\
\text { Sundays }\end{array}$ & 24.1 & $\begin{array}{l}\text { Birthweight in MMN, } 2981 \mathrm{~g} \text {; } \\
\text { birthweight in control, } 2977 \mathrm{~g} \\
\text { SGA in MMN, } 10.1 \% \text {; SGA in } \\
\text { control, } 11.8 \% \text { Gestation in } \\
\text { MMN, } 39.5 \text { weeks; gestation in } \\
\text { control, } 39.6 \text { weeks }\end{array}$ \\
\hline Nepal Janakpur & Osrin et al. [30] & Individual & 1200 & 112 days until birth & $\begin{array}{l}\text { Iron } 60 \mathrm{mg} \text {, folic } \\
\text { acid } 400 \mu \mathrm{g}\end{array}$ & $\begin{array}{l}\text { UNIMMAP; if } \\
\text { haemoglobin } \\
\text { concentration < } 70 \\
\text { g/L, given extra iron } \\
60 \text { mg daily and } \\
\text { anthelminthic } \\
\text { treatment; if } \\
\text { symptoms of night- } \\
\text { blindness, vitamin A } \\
2000 \mu \mathrm{g}\end{array}$ & 19.9 & $\begin{array}{l}\text { Birthweight, }+77 \mathrm{~g}(95 \% \mathrm{Cl} \text {, } \\
24-130 \mathrm{~g}) \\
\text { Gestation, } 0.2 \text { weeks ( } 95 \% \mathrm{Cl} \text {, } \\
-0.1 \text { to } 0.4 \text { weeks) } \\
\text { PMR in MMN, 49.0; PMR in } \\
\text { control, } 40.5 \\
\text { NMR in MMN, 30.6; NMR in } \\
\text { control, } 20.0\end{array}$ \\
\hline Nepal Sarlahi & $\begin{array}{l}\text { Christian } \\
\text { et al. [34] } \\
\text { Christian } \\
\text { et al. [31] }\end{array}$ & Cluster & $\begin{array}{l}14,036 \text { women under } \\
\text { pregnancy } \\
\text { surveillance; } 2007 \\
\text { pregnancies recruited } \\
\text { in } 169 \text { clusters }\end{array}$ & $\begin{array}{l}80 \text { days until } 12 \text { weeks } \\
\text { after birth }\end{array}$ & $\begin{array}{l}\text { Iron } 60 \mathrm{mg} \text {, folic } \\
\text { acid } 400 \mu \mathrm{g} \text {, Vit A } \\
1000 \mu \mathrm{g}\end{array}$ & $\begin{array}{l}\text { Vit } A \text {, thiamine, } \\
\text { riboflavin, vit } B_{3,} \text { vit } B_{6 \prime} \\
\text { folic acid, vit } B_{12} \text {, vit } C \text {, } \\
\text { vit } D \text {, vit } E \text {, vit } K_{1} \\
\text { copper, iron as ferrous } \\
\text { fumerate, magnesium } \\
\text { and zinc; albendazole } \\
\text { was offered in 2nd } \\
\text { and } 3 \text { rd trimesters }\end{array}$ & 19.3 & $\begin{array}{l}\text { Birthweight in MMN, } 2659 \mathrm{~g} ; \\
\text { birthweight in control, } 2652 \mathrm{~g} \\
\text { SGA in MMN, } 53.8 \% \text {; SGA in } \\
\text { control, } 51.7 \% \\
\text { PMR in MMN group, 87.1; } \\
\text { PMR in control group, 62.4 } \\
\text { NMR in MMN group, 54.0; } \\
\text { NMR in control group, } 36.3\end{array}$ \\
\hline
\end{tabular}

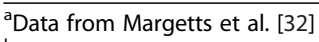

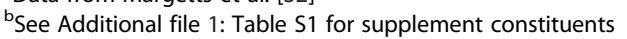

$B M I$ body mass index, Fe60 Fol iron $60 \mathrm{mg}$ and folic acid supplement, LMP last menstrual period, MMN multiple micronutrient supplement, NMR neonatal mortality per 1000 livebirths, PMR perinatal mortality per 1000 livebirths, RR relative risk, SGA small for gestational age, UNIMMAP United Nations International Multiple Micronutrient Preparation 
micronutrients as UNIMMAP in similar doses. The supplement used in Nepal Sarlahi contained micronutrients in similar doses (with $60 \mathrm{mg}$ iron), plus magnesium and vitamin $\mathrm{K}$, but no selenium or iodine [34]. The supplement used in Mexico included iron $62.4 \mathrm{mg}$ and magnesium $252 \mathrm{mg}$, and did not include copper, iodine or selenium [25]. In some cases, a comparison group of iron $60 \mathrm{mg}$ and folic acid $400 \mu \mathrm{g}$ was not available: Nepal Sarlahi included additional vitamin A [34], Mexico did not include folic acid [25], Indonesia used $30 \mathrm{mg}$ iron [29], and Bangladesh JiVitA used $27 \mathrm{mg}$ iron and $600 \mu \mathrm{g}$ folate [26]. Supplement constituents are shown in Additional file 1: Table S1. Supplementation was initiated in early to midpregnancy, with a range of median commencement gestation across studies of 14 weeks (Table 1).

\section{Follow-up reports}

We found 20 follow-up reports (Table 2 and Additional file 1: Figure S1). We divided the findings into five general categories: mortality [26, 27, 35-41], anthropometry [35, 38, 39, 41-44] and body composition [39, 44, 45], cardiovascular [39, 43, 46, 47], cognitive [37, 48-51], and respiratory [52]. Primary publications from the Bangladesh JiVitA and MINIMat trials included follow-up mortality data and were included in the list of follow-up reports. Meta-analyses were conducted for mortality, weight, height, head circumference and blood pressure outcomes.

\section{Mortality}

Follow-up reports from all trials systematically recorded and reported infant/child mortality as an outcome (Table 3). Meta-analysis showed no difference between intervention and control groups (risk difference, -0.05 per 1000 livebirths; $95 \% \mathrm{CI},-5.25$ to $5.15 ; \mathrm{I}^{2}, 8 \%$; Fig. 1). No difference by age was seen. Subgroup analysis including trials that used only the UNIMMAP supplement showed a risk difference of 3.41 per 1000 livebirths ( $95 \% \mathrm{CI},-4.45$ to 11.26 ; $\mathrm{I}^{2}$, $0 \%$; Additional file 1: Figure S2). Subgroup analysis for trials that used $60 \mathrm{mg}$ iron in control groups yielded a risk difference of 4.51 per 1000 livebirths (95\% CI, -2.91 to $11.94 ; \mathrm{I}^{2}, 0 \%$ ), and trials that used approximately $30 \mathrm{mg}$ iron in the control group yielded a risk difference of 0.41 per 1000 livebirths (95\% CI, -14.76 to $15.57 ; \mathrm{I}^{2}, 62 \%$; Additional file 1: Figure S3).

\section{Anthropometry}

Seven reports described anthropometry (Table 4). No differences were seen in any report at the most recent follow-up for WAZ, HAZ or head circumference, nor in any secondary anthropometric outcomes. Differences were seen at younger ages in two trials. In the Burkina Faso trial, greater mean WAZ $(\beta, 0.13 ; 95 \% \mathrm{CI}, 0.04$ to 0.23$)$ and length-for-age $z$ score ( $\beta, 0.13 ; 95 \% \mathrm{CI}, 0.02$ to 0.24 ) were seen in the multiple micronutrient supplement group, and a lower proportion were stunted at 1 year (hazard ratio, $0.73 ; 95 \% \mathrm{CI}, 0.60$ to 0.87 ), but there was no difference at 2.5 years of age [35]. In the Nepal Janakpur trial, greater mean WAZ ( $\beta, 0.14 ; 95 \% \mathrm{CI}, 0.00$ to 0.27 ) was seen in the multiple micronutrient supplement group at a mean of 2.5 years, but there was no difference at 8.5 years ( $\beta, 0.05 ; 95 \% \mathrm{CI},-0.09$ to 0.19$)$. Small increases were seen in head, chest, hip, and mid-upper arm circumferences at 2.5 years, but were also not present at 8.5 years $[39,43]$.

Effect modification by maternal BMI or child sex was not found in any report with the exception of the Bangladesh MINIMat trial, in which stunting was greater in boys in the MMN group (Males, $7.8 \%$; 95 \% CI, 2.0 to 13.6; Females, $1.8 \%$; $95 \% \mathrm{CI},-3.8$ to 7.3$)$. A test for interaction was not reported.

Meta-analyses for WAZ and HAZ showed no difference between multiple micronutrient and $60 \mathrm{mg}$ iron and folic acid groups. The differences in WAZ and HAZ were 0.02 (95\% CI, -0.03 to $0.07 ; \mathrm{I}^{2}, 0 \%$; Fig. 2 ) and 0.01 (95\% CI, -0.04 to $0.06 ; \mathrm{I}^{2}, 0$ \%; Fig. 3), respectively. Meta-analysis for head circumference was possible for three trials (Mexico, Bangladesh MINIMat and Nepal Janakpur) and showed no difference $(0.11 \mathrm{~cm}$; $95 \% \mathrm{CI},-0.03$ to 0.26 ; $\mathrm{I}^{2}, 0 \%$; Fig. 4). Subgroup analysis including UNIMMAP trials made little difference: WAZ 0.04 $(95 \% \mathrm{CI},-0.01$ to $0.09 ; \mathrm{I}^{2}, 0 \%$ ), HAZ 0.01 (95\% CI, -0.05 to $0.06 ; \mathrm{I}^{2}$, $0 \%)$, and head circumference $0.11 \mathrm{~cm}(95 \% \mathrm{CI},-0.05$ to $0.26 ; \mathrm{I}^{2}, 10 \%$; Additional file 1: Figure S2).

\section{Body composition}

The Bangladesh MINIMat trial found no difference in biceps, triceps, subscapular or suprailiac skinfold thicknesses. The Nepal Janakpur trial found an increase in triceps skinfold thickness at 2.5 years $(0.20 \mathrm{~mm}$; $95 \%$ CI, 0.00 to $0.40 \mathrm{~mm}$ ) [43], but no difference was found in any skinfold thickness at 8.5 years [39]. The Nepal Sarlahi trial found no difference in triceps or subscapular skinfold thickness at 7.5 years of age. Neither the Bangladesh MINIMat nor the Nepal Janakpur trial found a difference in lean mass or fat mass measured using bio-impedance [39, 45, 53, 54].

\section{Cardiovascular risk markers}

Cardiovascular outcomes were only examined in trials from South Asia (Table 4). The Bangladesh MINIMat and Nepal Janakpur trials measured blood pressure, while the Nepal Sarlahi trial investigated metabolic syndrome (blood pressure, $\mathrm{HbA}_{1 \mathrm{c}}$, urine microalbumin:creatinine, cholesterol, glucose, insulin, homeostasis model assessment of insulin resistance). The Nepal Janakpur cohort showed a reduction in mean systolic blood pressure of $2.5 \mathrm{mmHg}$ (95\% CI, 0.47 to 4.55 ) at 2.5 years of age, but no difference 
Table 2 Description of follow-up reports

\begin{tabular}{|c|c|c|c|c|c|c|c|}
\hline Location & Follow-up study & Age at follow- up & $\begin{array}{l}\text { Eligibility/exclusion } \\
\text { criteria for follow-up }\end{array}$ & $\begin{array}{l}\text { Risk of bias in loss to } \\
\text { follow-up }\end{array}$ & $\begin{array}{l}\text { \% follow-up in control } \\
\text { group }\end{array}$ & $\begin{array}{l}\% \text { follow-up in } \\
\text { intervention group }\end{array}$ & Outcome measures \\
\hline $\begin{array}{l}\text { Bangladesh } \\
\text { JiVitA }\end{array}$ & West et al. [26] & 6 months & None reported & $\begin{array}{l}5 \text { infants lost to follow-up; } \\
\text { assumed to be alive at } \\
180 \text { days }\end{array}$ & $100 \%$ & $100 \%$ & $\begin{array}{l}\text { Mortality assessed at 1, } 3 \\
\text { and } 6 \text { months }\end{array}$ \\
\hline \multirow[t]{5}{*}{$\begin{array}{l}\text { Bangladesh } \\
\text { MINIMat }\end{array}$} & Persson et al. [27] & 5 years & None reported & None & No reported losses & No reported losses & $\begin{array}{l}\text { Mortality assessed at } \\
5 \text { years }\end{array}$ \\
\hline & Khan et al. [42] & $\begin{array}{l}54 \text { months (monthly } \\
\text { to } 1 \text { year } \\
3 \text { monthly to } 2 \text { years) }\end{array}$ & Singletons & $\begin{array}{l}\text { None; imputation used for } \\
\text { missing data points }\end{array}$ & $\begin{array}{l}79.9 \% \text { of livebirths; } \\
86.5 \% \text { of children with } \\
\text { birth anthropometry }\end{array}$ & $\begin{array}{l}78.3 \% \text { of livebirths; } \\
87.9 \% \text { of children with } \\
\text { birth anthropometry }\end{array}$ & Length or height, weight \\
\hline & Khan et al. [45] & 54 months & $\begin{array}{l}\text { Singletons with birth } \\
\text { anthropometry }\end{array}$ & $\begin{array}{l}\text { Children lost more likely to } \\
\text { be first born and have lower } \\
\text { birthweight }\end{array}$ & $\begin{array}{l}72.3 \% \text { children with } \\
\text { birth anthropometry }\end{array}$ & $\begin{array}{l}70.9 \% \text { children with } \\
\text { birth anthropometry }\end{array}$ & $\begin{array}{l}\text { Mid-upper arm } \\
\text { circumference, skinfold } \\
\text { thickness, body composition } \\
\text { by bioelectrical impedance }\end{array}$ \\
\hline & Tofail et al. [48] & 7 months & $\begin{array}{l}\text { Subgroup of singletons } \\
\text { born May } 2002 \text { to } \\
\text { December } 2003\end{array}$ & $\begin{array}{l}\text { Small but significant } \\
\text { differences in children lost } \\
\text { to follow-up; mothers had } \\
\text { fewer children, higher } \\
\text { haemoglobin and shorter } \\
\text { gestation; no significant } \\
\text { difference in these between } \\
\text { allocation groups }\end{array}$ & $\begin{array}{l}\text { Unable to calculate as } \\
\text { the number of deaths } \\
\text { is only provided for all } \\
\text { allocation groups } \\
\text { combined }\end{array}$ & $\begin{array}{l}\text { Unable to calculate as } \\
\text { the number of deaths is } \\
\text { only provided for all } \\
\text { allocation groups } \\
\text { combined }\end{array}$ & $\begin{array}{l}\text { Cognition ('Support test' and } \\
\text { 'Cover test') } \\
\text { Motor development } \\
\text { (Psychomotor Developmental } \\
\text { Index of Bayley Scales of } \\
\text { Infant Development) } \\
\text { Behaviour (modified Wolke } \\
\text { in three domains: activity, } \\
\text { emotion and vocalization) }\end{array}$ \\
\hline & $\begin{array}{l}\text { Hawkesworth } \\
\text { et al. [46] }\end{array}$ & $\begin{array}{l}4 \text { years (mean } \\
4.6 \text { years) }\end{array}$ & $\begin{array}{l}\text { Singletons born at term } \\
\text { with birth anthropometry }\end{array}$ & $\begin{array}{l}\text { Children lost to follow-up } \\
\text { more likely to have been } \\
\text { firstborn and their mothers } \\
\text { on average } \sim 9 \text { months } \\
\text { younger with } 6 \text { months } \\
\text { longer education }\end{array}$ & $\begin{array}{l}69.1 \% \text { of livebirths; } \\
73.6 \% \text { of children with } \\
\text { birth anthropometry }\end{array}$ & $\begin{array}{l}67.9 \% \text { of livebirths; } \\
74.0 \% \text { of children with } \\
\text { birth anthropometry }\end{array}$ & $\begin{array}{l}\text { Blood pressure, kidney size } \\
\text { by ultrasound (restricted to } \\
\text { individuals born during the } \\
\text { second half of MINIMat } \\
\text { trial, June } 2003 \text { to June 2004), } \\
\text { and glomerular filtration rate } \\
\text { (restricted to individuals born } \\
\text { during first y of MINIMat trial, } \\
\text { June } 2002 \text { to June 2003) }\end{array}$ \\
\hline Burkina Faso & $\begin{array}{l}\text { Roberfroid } \\
\text { et al. [35] }\end{array}$ & $\begin{array}{l}\text { Monthly to } 12 \text { months } \\
\text { and } 30 \text { months }\end{array}$ & Singletons & None & $97.8 \%$ & $98.0 \%$ & $\begin{array}{l}\text { Length, weight, head, chest } \\
\text { and mid-upper arm } \\
\text { circumference }\end{array}$ \\
\hline \multirow[t]{3}{*}{ China } & Wang et al. [41] & $\begin{array}{l}3 \text { monthly to } \\
12 \text { months, } 6 \text { monthly } \\
\text { to } 30 \text { months }\end{array}$ & $\begin{array}{l}\text { Subgroup born in middle } \\
\text { year of } 3.5 \text { years } \\
\text { recruitment; congenital } \\
\text { disease excluded }(n=3)\end{array}$ & Not specified & $\begin{array}{l}84.9 \% \text { of selected } \\
\text { subgroup }\end{array}$ & $\begin{array}{l}81.3 \% \text { of selected } \\
\text { subgroup }\end{array}$ & Length, weight \\
\hline & Li et al. [49] & 3 monthly to 1 year & $\begin{array}{l}\text { Subgroup born in } \\
\text { middle year of } 3.5 \text { years } \\
\text { recruitment }\end{array}$ & $\begin{array}{l}\text { Small difference in Apgar } \\
\text { scores }\end{array}$ & $\begin{array}{l}89.7 \% \text { of selected } \\
\text { subgroup }\end{array}$ & $\begin{array}{l}88.6 \% \text { of selected } \\
\text { subgroup }\end{array}$ & $\begin{array}{l}\text { Cognition } \\
\text { Mental and Psychomotor } \\
\text { development (Bayley Scales } \\
\text { of Infant Development) }\end{array}$ \\
\hline & Li et al. [50] & $7-9$ years & $\begin{array}{l}\text { Singletons; children who } \\
\text { moved away were }\end{array}$ & None & $61.0 \%^{\mathrm{b}}$ & $60.7 \%^{b}$ & Cognition \\
\hline
\end{tabular}


Table 2 Description of follow-up reports (Continued)

\begin{tabular}{|c|c|c|c|c|c|c|c|}
\hline Guinea Bissau & $\begin{array}{l}\text { Andersen } \\
\text { et al. [36] }\end{array}$ & $0-2$ years & None reported & $\begin{array}{l}\text { Lost to follow-up different } \\
\text { for maternal weight, age, } \\
\text { height and parity; no } \\
\text { difference between trial } \\
\text { groups }\end{array}$ & $77.1 \%$ & $77.8 \%$ & $\begin{array}{l}\text { Mortality by routine } \\
\text { surveillance every } 3 \text { months } \\
\text { up to } 1 \text { year and every } \\
6 \text { months after } 1 \text { year }\end{array}$ \\
\hline Indonesia & Prado et al. [37] & 42 months & $\begin{array}{l}2369 \text { of } 41,839 \text { women } \\
\text { enrolled randomly } \\
\text { assigned to blood tests; } \\
\text { children of } 549 \text { of these } \\
\text { women who gave birth } \\
\text { in a } 6 \text { month period }\end{array}$ & None reported & $\begin{array}{l}94.5 \% \text { of selected } \\
\text { subgroup }\end{array}$ & $\begin{array}{l}92.8 \% \text { of selected } \\
\text { subgroup }\end{array}$ & $\begin{array}{l}\text { Cognition } \\
\text { Adapted, validated tests for } \\
\text { motor, language, visual } \\
\text { attention/spatial, executive } \\
\text { and socio-emotional } \\
\text { function; adjusted analyses } \\
\text { presented: confounders } \\
\text { included 'home observation } \\
\text { and measurement of } \\
\text { environment' inventory } \\
\text { score, child haemoglobin, } \\
\text { mother's mid-upper arm } \\
\text { circumference, birth weight, } \\
\text { MMN adherence }\end{array}$ \\
\hline Mexico & $\begin{array}{l}\text { Ramakrishnan } \\
\text { et al. [38] }\end{array}$ & $\begin{array}{l}3 \text { months } \\
24 \text { months }\end{array}$ & $\begin{array}{l}\text { Singletons; children } \\
\text { from antenatal trial } \\
\text { subsequently } \\
\text { randomised to receive } \\
\text { MMN or iron + Vit A }\end{array}$ & $\begin{array}{l}\text { Lost to follow-up younger } \\
\text { mothers, more educated } \\
\text { and less parous }\end{array}$ & $\begin{array}{l}24.9 \% \text { of livebirths in } \\
\text { childhood } \\
\text { randomisation control } \\
\text { group; } 69.3 \% \text { of } \\
\text { children randomised in } \\
\text { childhood control }\end{array}$ & $\begin{array}{l}26.2 \% \text { of livebirths in } \\
\text { the childhood } \\
\text { randomisation MMN } \\
\text { group; } 74.2 \% \text { of } \\
\text { children randomised in } \\
\text { childhood control }\end{array}$ & $\begin{array}{l}\text { Height, weight, head } \\
\text { circumference }\end{array}$ \\
\hline \multirow[t]{3}{*}{ Nepal Janakpur } & Vaidya et al. [43] & $2-3$ years & None reported & $\begin{array}{l}\text { Difference in lost to follow- } \\
\text { up in maternal education, } \\
\text { urban/rural residence and } \\
\text { main household occupation }\end{array}$ & $85.8 \%$ & $86.5 \%$ & $\begin{array}{l}\text { Height, weight, head, chest, } \\
\text { waist, hip and mid-upper } \\
\text { arm circumferences, skinfold } \\
\text { thickness, blood pressure }\end{array}$ \\
\hline & $\begin{array}{l}\text { Devakumar } \\
\text { et al. [39] }\end{array}$ & $7-9$ years & None reported & $\begin{array}{l}\text { Small difference in lost to } \\
\text { follow-up in maternal } \\
\text { education and urban/rural } \\
\text { residence }\end{array}$ & $80.5 \%$ & $79.2 \%$ & $\begin{array}{l}\text { Height, weight, body } \\
\text { composition by bioelectrical } \\
\text { impedance, skinfold } \\
\text { thickness, head, chest, waist, } \\
\text { hip, mid-upper arm and } \\
\text { upper leg circumferences, } \\
\text { kidney dimensions, blood } \\
\text { pressure }\end{array}$ \\
\hline & $\begin{array}{l}\text { Devakumar } \\
\text { et al. [52] }\end{array}$ & $7-9$ years & None reported & $\begin{array}{l}\text { Small difference in lost to } \\
\text { follow-up in maternal } \\
\text { education and urban/rural } \\
\text { residence; small number } \\
(n=5) \text { with learning } \\
\text { difficulties unable to } \\
\text { complete spirometry }\end{array}$ & $80.5 \%$ & $79.2 \%$ & $\begin{array}{l}\text { Spirometry, respiratory } \\
\text { illness, asthma }\end{array}$ \\
\hline
\end{tabular}

Mental development

to 1 year and every

groups

children of 549 of these

$94.5 \%$ of selected
subgroup

$92.8 \%$ of selected

dapted, validated tests for

unction; adjusted analyses

pented: confounders

and measurement of

anvironment' inventory

score, child haemoglobin

mother's mid-upper arm

MMN adherence

childhood

eight, weight, hea

group; $74.2 \%$ of

children randomised in

86.5

Height, weight, head, chest, wist, hip and mid-upper

hickness, head, chest, waist,

ip, mid-upper arm and

pper leg circumferences,

ressure

pirometry, respiratory

follow-up in maternal

illness, asthma

complete spiromety 
Table 2 Description of follow-up reports (Continued)

\begin{tabular}{|c|c|c|c|c|c|c|c|}
\hline \multirow[t]{4}{*}{ Nepal Sarlahi } & Stewart et al. [44] & $6-8$ years & $\begin{array}{l}3669 \text { also in subsequent } \\
\text { childhood trial of iron, } \\
\text { folic acid and zinc }\end{array}$ & $\begin{array}{l}\text { Lost to follow-up more } \\
\text { likely to be of Pahadi (hill) } \\
\text { ethnicity, have a literate } \\
\text { mother and own a radio, } \\
\text { and less likely to own cattle }\end{array}$ & $89.2 \%$ & $91.2 \%$ & $\begin{array}{l}\text { Height, weight, mid-upper } \\
\text { arm circumference, waist } \\
\text { circumference, skinfold } \\
\text { thickness }\end{array}$ \\
\hline & Stewart et al. [47] & $6-8$ years & $\begin{array}{l}3673 \text { also in subsequent } \\
\text { childhood trial of iron, } \\
\text { folic acid and zinc }\end{array}$ & $\begin{array}{l}\text { Loss to follow-up did not } \\
\text { differ between groups; } \\
\text { large number did not } \\
\text { complete all tests; children } \\
\text { with missing data less likely } \\
\text { to be of Pahadi ethnicity or } \\
\text { to have had any schooling, } \\
\text { and had slightly lower BMl }\end{array}$ & $\begin{array}{l}\text { Overall } 84.1 \% \text {; number } \\
\text { of participants varied } \\
\text { for each test or } \\
\text { measurement }\end{array}$ & $\begin{array}{l}\text { Overall } 85.1 \% \text {; number } \\
\text { of participants varied for } \\
\text { each test or measurement }\end{array}$ & $\begin{array}{l}\text { Metabolic syndrome } \\
\text { BMl, waist circumference, } \\
\text { blood pressure, HbA } \mathrm{H}_{1 c} \text { urine } \\
\text { microalbumin:creatinine, } \\
\text { cholesterol, glucose, insulin, } \\
\text { homeostasis model } \\
\text { assessment }\end{array}$ \\
\hline & Christian et al. [51] & 7-9 years & $\begin{array}{l}\text { In control group of } \\
\text { subsequent iron and zinc } \\
\text { pre-school trial; children } \\
\text { followed up in this study } \\
\text { represent } 23 \% \text { of live } \\
\text { births in relevant } \\
\text { allocation groups in the } \\
\text { original trial }\end{array}$ & $\begin{array}{l}\text { Main loss to follow-up was } \\
\text { exclusion of children taking } \\
\text { part in postnatal supple } \\
\text { mentation trial; children lost } \\
\text { more likely to be of Pahadi } \\
\text { ethnicity, literate mother, } \\
\text { own a radio and less likely } \\
\text { to own cattle }\end{array}$ & $75.2 \%$ of subgroup & $84.2 \%$ of subgroup & $\begin{array}{l}\text { Cognition } \\
\text { Universal Non-verbal } \\
\text { Intelligence Test Movement } \\
\text { Assessment Battery for } \\
\text { Children } \\
\text { Finger-tapping test } \\
\text { Executive Function (Stroop } \\
\text { Numbers Test, backward } \\
\text { digit span, go/no-go) } \\
\text { Environment (Middle } \\
\text { Childhood Home } \\
\text { Observation for the } \\
\text { Measurement of the } \\
\text { Environment inventory) } \\
\text { Maternal intelligence } \\
\text { (Raven Coloured Progressive } \\
\text { Matrices) }\end{array}$ \\
\hline & Christian et al. [40] & $6-8$ years & None reported & None reported & $96.1 \%$ & $96.0 \%$ & Mortality \\
\hline
\end{tabular}

a Defined as total number measured as a proportion of the total number available for measurement (livebirths minus deaths), as a percentage

${ }^{\mathrm{b} T h e}$ percentage excludes 1643 families who have moved out of the area

$M M N$ multiple micronutrient supplement 
Table 3 Mortality outcomes

\begin{tabular}{|c|c|c|c|c|c|c|}
\hline Location & Follow-up study & Deaths in control group ${ }^{a}$ & $\begin{array}{l}\text { Livebirths in } \\
\text { control group }\end{array}$ & $\begin{array}{l}\text { Deaths in } \\
\text { intervention group }\end{array}$ & $\begin{array}{l}\text { Livebirths in } \\
\text { MMN group }\end{array}$ & $\begin{array}{l}\text { Mortality difference }^{a} \\
\text { MMN - control, per } \\
1000 \text { livebirths (95\% Cl) }\end{array}$ \\
\hline $\begin{array}{l}\text { Bangladesh, } \\
\text { JiVitA }\end{array}$ & West et al. [26] & $\begin{array}{l}764 \\
625 \text { neonatal } \\
139 \text { at } 29-180 \text { days }\end{array}$ & 14,142 & $\begin{array}{l}741 \\
626 \text { neonatal } \\
115 \text { at } 29-180 \text { days }\end{array}$ & 14,374 & $-2.5(-8.1 \text { to } 3.1)^{b}$ \\
\hline $\begin{array}{l}\text { Bangladesh, } \\
\text { MINIMat }\end{array}$ & Persson et al. [27] & $\begin{array}{l}33 \\
23 \text { neonatal } \\
10 \text { post-neonatal to } \\
5 \text { years }\end{array}$ & 612 & $\begin{array}{l}34 \\
25 \text { neonatal } \\
9 \text { post-neonatal to } 5 \text { years }\end{array}$ & 595 & $3.2(-22.6$ to 29.0$)$ \\
\hline Burkina Faso & $\begin{array}{l}\text { Roberfroid } \\
\text { et al. [35] }\end{array}$ & $\begin{array}{l}45 \\
7 \text { neonatal } \\
38 \text { post-neonatal } \\
\text { to } 30 \text { months }\end{array}$ & 644 & $\begin{array}{l}55 \\
11 \text { neonatal } \\
44 \text { post-neonatal to } \\
30 \text { months }\end{array}$ & 650 & $14.7(-14.3$ to 43.8$)$ \\
\hline China $^{c}$ & Wang et al. [41] & $\begin{array}{l}16 \\
16 \text { neonatal } \\
0 \text { in children born } \\
\text { in } 2004\end{array}$ & 1499 & $\begin{array}{l}20 \\
18 \text { neonatal } \\
2 \text { in children born in } 2004\end{array}$ & 1469 & $6.10(-3.9 \text { to } 17.3)^{b}$ \\
\hline Guinea Bissau & Andersen et al. [36] & $\begin{array}{l}57 \\
25 \text { neonatal } \\
9 \text { at } 29-91 \text { days } \\
10 \text { at } 92-365 \text { days } \\
13 \text { at } 366-730 \text { days }\end{array}$ & 519 & $\begin{array}{l}65 \\
29 \text { neonatal } \\
6 \text { at } 29-91 \text { days } \\
21 \text { at } 92-365 \text { days } \\
9 \text { at } 366-730 \text { days }\end{array}$ & 528 & $13.3(-25.8$ to 52.4$)$ \\
\hline Indonesia ${ }^{c}$ & Prado et al. [37] & $\begin{array}{l}580 \text { infant } \\
17 \text { in subsample }\end{array}$ & 14,053 & $\begin{array}{l}490 \text { infant } \\
12 \text { in subsample }\end{array}$ & 14,373 & $-13.2(-33.4 \text { to } 7.1)^{b}$ \\
\hline Mexico $^{c}$ & $\begin{array}{l}\text { Ramakrishnan } \\
\text { et al. [38] }\end{array}$ & $\begin{array}{l}7 \\
6 \text { early deaths } \\
1 \text { in control group of } \\
\text { childhood randomisation }\end{array}$ & 460 & $\begin{array}{l}4 \\
4 \text { early deaths }\end{array}$ & 456 & $-10.30(-29.30$ to 6.60$)$ \\
\hline Nepal Janakpur & $\begin{array}{l}\text { Devakumar } \\
\text { et al. [39] }\end{array}$ & $\begin{array}{l}22 \\
12 \text { neonatal } \\
6 \text { post-neonatal } \\
4 \text { at } 1-8 \text { years }\end{array}$ & 564 & $\begin{array}{l}23 \\
17 \text { neonatal } \\
4 \text { post-neonatal } \\
2 \text { at } 1-8 \text { years }\end{array}$ & 567 & $1.6(-21.2$ to 24.3$)$ \\
\hline Nepal Sarlahi & Christian et al. [40] & $\begin{array}{l}54 \\
34 \text { before } 91 \text { days } \\
20 \text { at } 91 \text { days to } 7 \text { years }\end{array}$ & 773 & $\begin{array}{l}81 \\
52 \text { before } 91 \text { days } \\
29 \text { at } 91 \text { days to } 7 \text { years }\end{array}$ & 872 & $23.0(-5.2 \text { to } 51.3)^{\mathrm{b}}$ \\
\hline
\end{tabular}

${ }^{a}$ Mortality figures given for the most recent follow-up. In the case of the Bangladesh MINIMat study, this was the trial paper

${ }^{b}$ The analysis accounts for clustering in relevant trials. Design effects of 1.15, 1.20 and 1.20 were predicted in the Bangladesh JiVitA, Indonesia and Nepal Sarlahi trials, respectively $[26,29,34]$; the China trial did not report a figure and we used a design effect of 1.20

'The follow-up report described a subgroup of children; confidence intervals were created using a simulation approach, as described in more detail in the methods section

at 8.5 years $(0.02 \mathrm{mmHg} ;-1.02$ to 1.05$)$ [39, 43]. The Bangladesh MINIMat cohort showed no difference at 4.5 years compared with a control group who received iron $30 \mathrm{mg}$ and folic acid [46]. The Nepal Sarlahi trial found neither a difference in blood pressure at 7.5 years, nor a difference in other cardiovascular risk markers compared with a control group who received iron $60 \mathrm{mg}$ and folic acid [47]. Meta-analysis of the three trials showed no difference in blood pressure: the difference in systolic blood pressure was $0.11 \mathrm{mmHg}\left(95 \% \mathrm{CI},-0.41\right.$ to 0.63 ; $\mathrm{I}^{2}$, $0 \%$ ), and in diastolic pressure $0.47 \mathrm{mmHg}$ (95\% CI, -0.01 to $0.95 ; \mathrm{I}^{2}, 0 \%$; Additional file 1: Figure S4). Subgroup analysis for trials that used iron $60 \mathrm{mg}$ in the control group was similar: systolic blood pressure difference $0.16 \mathrm{mmHg}$ ( $95 \% \mathrm{CI},-0.54$ to $0.87 ; \mathrm{I}^{2}, 0 \%$ ), and diastolic $0.37 \mathrm{mmHg}$ (95\% CI, -0.35 to $1.08 ; \mathrm{I}^{2}, 0 \%$; Additional file 1: Figure S3).

\section{Cognitive function}

The Bangladesh MINIMat, China, and Indonesia trials all assessed subgroups of children: in Bangladesh, children born in a 19-month period, at 7 months of age [48]; in China, in the middle year of the trial up to 1 year of age [49] and at 8.8 years [50]; and in Indonesia, in women assigned to blood tests and whose children were born in a 6-month time period, at 3.5 years of age [37]. The Nepal Sarlahi study administered cognitive, motor and executive function tests at 7-9 years of age. Mean cognitive scores were a little lower for the MMN group compared to iron, folic acid and vitamin A (Universal Nonverbal Intelligence Test score, $-2.4 ; 95 \% \mathrm{CI},-4.6$ to -0.2 ). Results of motor and executive function tests were mixed [51]. The Bangladesh MINIMat and China trials found no difference in motor or psychomotor scores $[48,49]$. The Indonesia trial found an increase in motor ability in an adjusted 


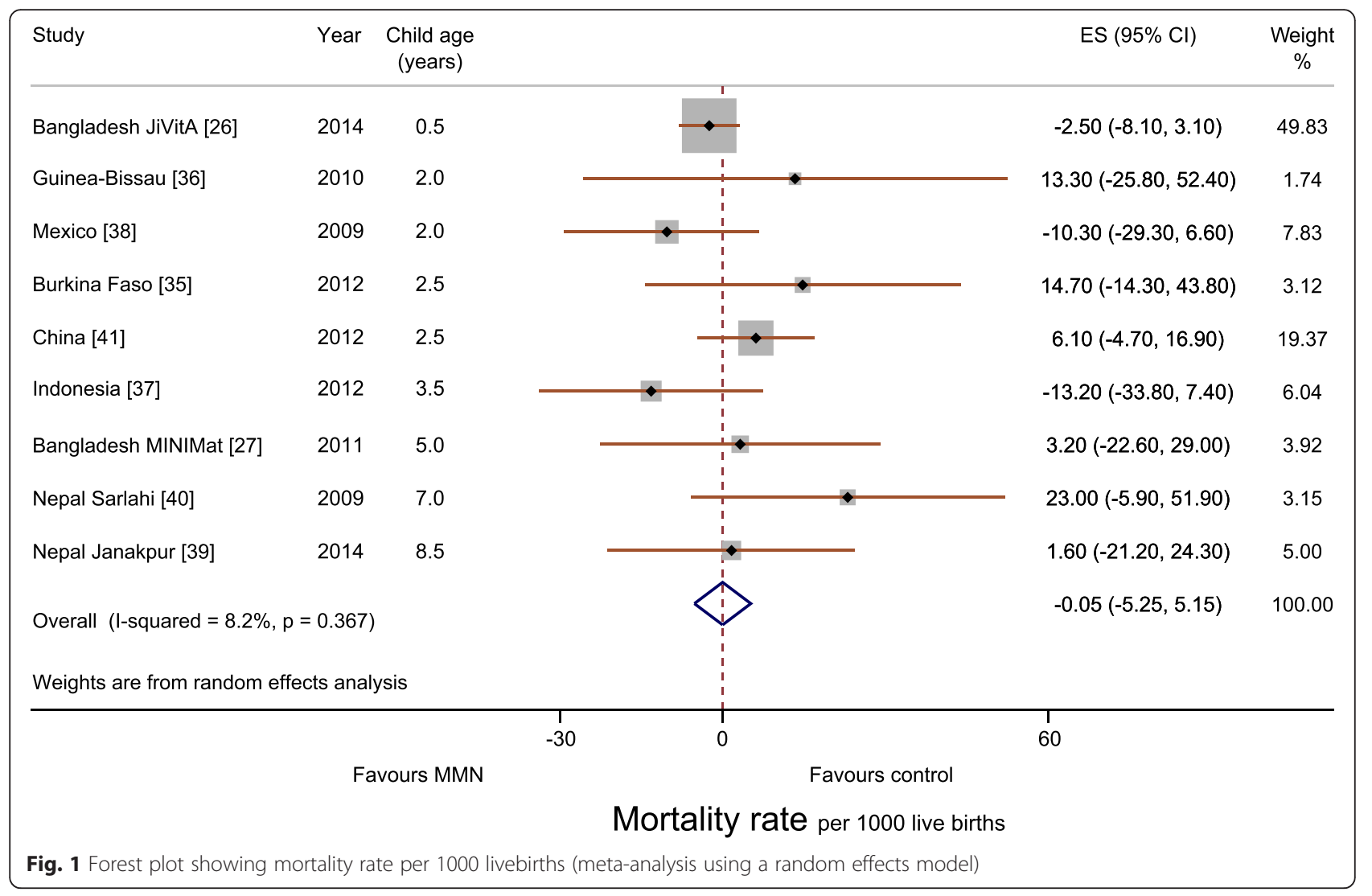

analysis expressed as a fraction of the variation of the score $(0.19 ; 95 \%$ CI, 0.02 to 0.37) [37]. The Bangladesh MINIMat follow-up found no difference in problem solving or behaviour [48]. In the China trial, there were no differences at 3 or 6 months, but age-adjusted scores at 1 year were higher for mental development in the MMN supplementation group (1.20 points; $95 \% \mathrm{CI}, 0.32$ to 2.08 : equivalent to about 6 days of age) [49]. At 8.8 years of age, there were no differences in cognitive scores compared to folic acid or to iron and folic acid groups [50]. The Indonesia trial follow-up found no difference in visuospatial and visual attention, executive functioning, language ability, or socioemotional development [37].

For completeness, we mention stratified analyses. In the Bangladesh MINIMat trial, stratification by maternal BMI, combining the early and usual food groups together, showed an increase in Psychomotor Development Index in children whose mothers had been allocated to MMN supplements and had $\mathrm{BMI}<18.5 \mathrm{~kg} / \mathrm{m}^{2}(0.22 z$ scores; 0.01 to 0.42 ; interaction term, $P=0.05$ ) [48]. In Indonesia, MMN supplementation was associated with greater motor ability ( $\beta=0.35 z$ scores; $95 \% \mathrm{CI}, 0.01$ to 0.69 , interaction term, $P=0.04)$ and visual attention/spatial ability $(\beta=0.35$; $95 \% \mathrm{CI}, 0.08$ to 0.63 , interaction term, $P=0.01$ ) in children of undernourished mothers (MUAC, $<23.5 \mathrm{~cm}$ ).
These differences were equivalent to approximately 5 months of age [37].

\section{Respiratory}

The Nepal Janakpur trial investigated lung function at 8.5 years of age. Spirometry data were obtained from 836 children, with 793 (95\%) achieving optimal results using American Thoracic Society/European Respiratory Society guidelines [55]. No difference in lung function was found between allocation groups: forced expiratory volume in the first second, $-0.01 \mathrm{~L}(95 \% \mathrm{CI},-0.04$ to $0.02 \mathrm{~L}$ ); forced vital capacity, $-0.01 \mathrm{~L}(95 \% \mathrm{CI},-0.04$ to $0.02 \mathrm{~L}$ ) [52].

\section{Assessment of bias \\ Trials}

The trials were considered high quality and bias was not thought to be important. There was potential selection bias in the Guinea-Bissau trial as a result of inadequately concealed allocation [24], and potential attrition bias for the Nepal Janakpur and Mexico trials, in which exclusions prior to randomization were not reported $[25,30]$.

\section{Follow-up reports}

The trials were powered on the primary outcomes of gestational age and birthweight (and mortality, in the 
Table 4 Anthropometry, body composition and cardiovascular results

\begin{tabular}{|c|c|c|c|c|c|c|c|c|c|c|c|}
\hline & $\begin{array}{l}\text { Follow-up } \\
\text { study }\end{array}$ & $\begin{array}{l}\text { Weight } \\
\text { difference ( } z \\
\text { scores) }\end{array}$ & $\begin{array}{l}\text { \% Underweight } \\
\text { (<-2 z scores) }\end{array}$ & $\begin{array}{l}\text { Height } \\
\text { difference ( } z \\
\text { scores) }\end{array}$ & $\begin{array}{l}\text { \% Stunted } \\
(<-2 \text { z scores })\end{array}$ & $\begin{array}{l}\text { Weight-for- } \\
\text { height/length } \\
\text { or BMl for age }\end{array}$ & $\begin{array}{l}\text { \% Wasted } \\
\text { or low BMl } \\
(<-2 z \\
\text { scores) }\end{array}$ & $\begin{array}{l}\text { Body } \\
\text { composition } \\
\text { and skin fold } \\
\text { thickness }\end{array}$ & $\begin{array}{l}\text { Body } \\
\text { circumferences }\end{array}$ & Blood pressure & Other \\
\hline \multirow[t]{3}{*}{$\begin{array}{l}\text { Bangladesh } \\
\text { MINIMat }\end{array}$} & $\begin{array}{l}\text { Khan et al. [42] } \\
\text { Anthro }^{\mathrm{a}}\end{array}$ & $\begin{array}{l}\text { Calculated } \\
\text { difference: } 0 \\
(-0.114 \text { to } \\
0.114)\end{array}$ & & $\begin{array}{l}\text { Calculated } \\
\text { difference: - } \\
0.01 \text { (-0.13 to } \\
0.11)\end{array}$ & $\begin{array}{l}4.8 \%(0.8-8.9) \\
\text { more stunting } \\
\text { across all } \\
\text { measurements }\end{array}$ & $\begin{array}{l}\text { Calculated } \\
\text { difference: Wt- } \\
\text { for-ht } z \text { score, } \\
0.01 \text { (-0.09 to } \\
0.11 \text { ) }\end{array}$ & & & & & \\
\hline & $\begin{array}{l}\text { Khan et al. [45] } \\
\text { Body comp }{ }^{\text {a }}\end{array}$ & & & & & & & $\begin{array}{l}\text { Lean mass, } \\
0.000 \mathrm{~kg} \\
(-0.123 \text { to } \\
0.125 \mathrm{~kg}) \text {; fat } \\
\text { mass, } 0.001 \mathrm{~kg} \\
(-0.058 \text { to } \\
0.061 \mathrm{~kg}) \text {; no } \\
\text { difference in } \\
\text { biceps, triceps, } \\
\text { subscap or } \\
\text { suprailiac } \\
\text { skinfold } \\
\text { thicknesses }\end{array}$ & $\begin{array}{l}\text { Calculated } \\
\text { difference: } \\
\text { head, } 0.02 \mathrm{~cm} \\
(-0.20 \text { to } 0.24) \\
\text { MUAC, } 0.11 \mathrm{~cm} \\
(-0.04 \text { to } \\
0.26 \mathrm{~cm})\end{array}$ & & \\
\hline & $\begin{array}{l}\text { Hawkesworth } \\
\text { et al. [46] }\end{array}$ & & & & & & & & & $\begin{array}{l}\text { Compared to } \\
30 \text { mg iron } \\
\text { control adjusted } \\
\text { for iron } \\
\text { intervention } \\
\text { dummy and } \\
\text { food } \\
\text { intervention } \\
\text { variables: } \\
\text { Systolic, } 0.05 \\
\text { (-0.71 to } 0.81) \text {; } \\
\text { Diastolic, } 0.55 \\
(-0.10 \text { to } 1.20)\end{array}$ & $\begin{array}{l}\text { No difference in } \\
\text { kidney volumes } \\
\text { compared to } \\
30 \text { mg iron }\end{array}$ \\
\hline $\begin{array}{l}\text { Burkina } \\
\text { Faso }\end{array}$ & $\begin{array}{l}\text { Roberfroid } \\
\text { et al. [35] }\end{array}$ & $\begin{array}{l}0.13(-0.01 \\
\text { to } 0.27)^{b}\end{array}$ & $\begin{array}{l}\text { Hazard ratio in } \\
1 \text { st year of life } \\
0.84(0.70,1.02)^{c}\end{array}$ & $\begin{array}{l}-0.02 \text { ( }-0.18 \text { to } \\
0.14)^{\mathrm{b}} \text { Length } \\
\text { for age was } \\
\text { significantly } \\
\text { higher in the } \\
\text { first year, but } \\
\text { this disappeared } \\
\text { by } 30 \text { months }\end{array}$ & $\begin{array}{l}\text { Hazard ratio in } \\
1 \text { st year of life, } \\
0.73(0.60-0.87)^{c}\end{array}$ & $\begin{array}{l}0.20(0.06-0.34)^{b} \\
\text { Wt-for-ht was } \\
\text { lower initially } \\
\text { but higher in } \\
\text { MMN from } \geq \\
10 \text { months }\end{array}$ & $\begin{array}{l}\text { Hazard ratio } \\
\text { in 1st year } \\
\text { of life, } 1.10 \\
(0.90-1.35)^{c}\end{array}$ & & $\begin{array}{l}\text { MUAC for age } z, \\
0.18(-2.93 \text { to } \\
3.29)^{b}\end{array}$ & & \\
\hline China & $\begin{array}{l}\text { Wang } \\
\text { et al. [41] }\end{array}$ & $\begin{array}{l}\text { Pooled (1- } \\
30 \text { months) } \\
\text { adjusted } \\
\text { difference: } \\
0.03(-0.05 \\
\text { to } 0.10)^{d}\end{array}$ & $\begin{array}{l}\text { Pooled (1-30 } \\
\text { months) } \\
\text { adjusted. OR } \\
0.95(0.71,1.29)\end{array}$ & $\begin{array}{l}\text { Pooled (1-30 } \\
\text { months) } \\
\text { adjusted } \\
\text { difference, } 0.02 \\
(-0.07 \text { to } 0.10)^{d}\end{array}$ & $\begin{array}{l}\text { Pooled (1-30 } \\
\text { months) } \\
\text { adjusted; OR, } \\
0.82(0.63-1.07)^{d}\end{array}$ & $\begin{array}{l}\text { Pooled wt-for- } \\
\text { length ( } 1-30 \\
\text { months) } \\
\text { adjusted differ } \\
\text { ence, } 0.03 \\
(-0.05 \text { to } 0.11)^{d}\end{array}$ & $\begin{array}{l}\text { Pooled wt- } \\
\text { for-length } \\
\text { (1-30 } \\
\text { months) } \\
\text { adjusted; OR, }\end{array}$ & & & & \\
\hline
\end{tabular}


Table 4 Anthropometry, body composition and cardiovascular results (Continued)

\begin{tabular}{|c|c|c|c|c|c|c|c|c|c|c|c|}
\hline & & & & & & & $\begin{array}{l}0.89(0.58- \\
1.36)^{d}\end{array}$ & & & & \\
\hline Mexico & $\begin{array}{l}\text { Ramakrishnan } \\
\text { et al. [38] }\end{array}$ & $\begin{array}{l}\text { Calculated } \\
\text { difference: - } \\
0.1(-0.34 \\
\text { to } 0.14)\end{array}$ & & $\begin{array}{l}\text { Calculated } \\
\text { difference: } 0.2 \\
\text { (-0.08 to } 0.48)\end{array}$ & & $\begin{array}{l}\text { Calculated } \\
\text { difference: } \\
\text { Wt-for-ht }-0.2 \\
(-0.42 \text { to } 0.02)\end{array}$ & & & $\begin{array}{l}\text { Calculated } \\
\text { difference: } \\
\text { head, } 0.2 \mathrm{~cm} \\
(-0.42 \text { to } 0.82)\end{array}$ & & \\
\hline \multirow[t]{2}{*}{$\begin{array}{l}\text { Nepal } \\
\text { Janakpur }\end{array}$} & Vaidya et al. [43] & $\begin{array}{l}0.14(0.00- \\
0.27)\end{array}$ & $\begin{array}{l}37.8 \% \text { in } \\
\text { control, } 36.6 \% \\
\text { in MMN }\end{array}$ & $\begin{array}{l}0.08 \text { (-0.06 to } \\
0.22)\end{array}$ & $\begin{array}{l}60 \% \text { in } \\
\text { control, } 56.7 \% \\
\text { in MMN }\end{array}$ & $\begin{array}{l}\text { Wt-for-ht } 0.12 \\
(-0.02 \text { to } 0.26)\end{array}$ & $\begin{array}{l}5.5 \% \text { in } \\
\text { control, } \\
6.3 \% \text { in } \\
\text { MMN }\end{array}$ & $\begin{array}{l}\text { Triceps, } \\
0.20 \mathrm{~mm}(0.00- \\
0.40 \mathrm{~mm})\end{array}$ & $\begin{array}{l}\text { Head, } 0.24 \mathrm{~cm} \\
(0.06-0.43 \mathrm{~cm}) \\
\text { MUAC, } 0.24 \mathrm{~cm} \\
(0.11-0.37 \mathrm{~cm})\end{array}$ & $\begin{array}{l}\text { Systolic, } \\
-2.5 \mathrm{mmHg} \\
(0.47- \\
4.55 \mathrm{mmHg}) ; \\
\text { Diastolic, } \\
-1.5 \mathrm{mmHg} \\
(-3.1 \mathrm{to} \\
0.4 \mathrm{mmHg})\end{array}$ & \\
\hline & $\begin{array}{l}\text { Devakumar } \\
\text { et al. [39] }\end{array}$ & $\begin{array}{l}0.05(-0.09 \\
\text { to } 0.19)\end{array}$ & $\begin{array}{l}\text { Not recorded } \\
\text { by trial group }\end{array}$ & $\begin{array}{l}0.02(-0.10 \text { to } \\
0.15)\end{array}$ & $\begin{array}{l}\text { Not recorded } \\
\text { by trial group }\end{array}$ & $\begin{array}{l}\text { BMl for age } \\
0.04(-0.09 \\
\text { to } 0.18)\end{array}$ & $\begin{array}{l}\text { Not } \\
\text { recorded by } \\
\text { trial group }\end{array}$ & $\begin{array}{l}\text { Lean mass, } \\
-0.05 \mathrm{~kg}(-0.43 \\
\text { to } 0.34 \mathrm{~kg}) ; \text { fat } \\
\text { mass, }-0.07 \mathrm{~kg} \\
(-0.32 \text { to } \\
0.18 \mathrm{~kg}) ; \text { no } \\
\text { difference in } \\
\text { biceps, triceps, } \\
\text { subscapular } \\
\text { and suprailiac } \\
\text { skinfold } \\
\text { thicknesses }\end{array}$ & $\begin{array}{l}\text { Head, } 0.18 \mathrm{~cm} \\
(-0.02 \text { to } 0.38) \text {; } \\
\text { MUAC, } 0.04 \\
(-0.15 \text { to } \\
0.23 \mathrm{~cm})\end{array}$ & $\begin{array}{l}\text { Systolic, } \\
0.02 \mathrm{mmHg} \\
(-1.02 \text { to } \\
1.05 \mathrm{mmHg}) ; \\
\text { Diastolic, } \\
0.13 \mathrm{mmHg} \\
(-0.93 \text { to } \\
1.19 \mathrm{mmHg})\end{array}$ & $\begin{array}{l}\text { No difference in } \\
\text { kidney dimensions; } \\
\text { exclusion of } \\
\text { children with } \\
\text { chronic or major } \\
\text { illness made no } \\
\text { difference }\end{array}$ \\
\hline \multirow[t]{2}{*}{$\begin{array}{l}\text { Nepal } \\
\text { Sarlahi }\end{array}$} & $\begin{array}{l}\text { Stewart } \\
\text { et al. [44] }\end{array}$ & $\begin{array}{l}\text { Calculated } \\
\text { difference: } \\
-0.04 \text { ( } 95 \% \\
\mathrm{Cl},-0.15 \text { to } \\
0.07)^{\mathrm{e}}\end{array}$ & $\begin{array}{l}\text { Calculated } \\
\text { difference: } 0.3 \% \\
(95 \% \mathrm{Cl},-5.4 \\
\text { to } 6.0)^{\mathrm{e}}\end{array}$ & $\begin{array}{l}\text { Calculated } \\
\text { difference: } \\
-0.02(-0.13 \\
\text { to } 0.09)^{\mathrm{e}}\end{array}$ & $\begin{array}{l}\text { Calculated } \\
\text { difference: } \\
3.7 \%(-2.0-9.4)^{\mathrm{e}}\end{array}$ & $\begin{array}{l}\text { BMl for age } \\
\text { calculated } \\
\text { difference: - } \\
0.04(-0.14 \\
\text { to } 0.06)^{e}\end{array}$ & & $\begin{array}{l}\text { Triceps: FeFol } \\
+ \text { vit A, } \\
5.84 \text { mm; } \\
\text { MMN, } 5.9 \mathrm{~mm} ; \\
\text { Subscap: MMN, } \\
4.81 \mathrm{~mm} ; \\
\text { FeFol + vit A } \\
4.75 \mathrm{~mm}\end{array}$ & $\begin{array}{l}\text { MUAC: FeFol + } \\
\text { vit A, } 15.4 \mathrm{~cm} \text {; } \\
\text { MMN, } 15.4 \mathrm{~cm}\end{array}$ & & \\
\hline & $\begin{array}{l}\text { Stewart } \\
\text { et al. [47] }\end{array}$ & & & & & & & & $\begin{array}{l}\text { Waist: FeFol + } \\
\text { vita A, } 51.27 \mathrm{~cm} \text {; } \\
\text { MMN, } 51.22 \mathrm{~cm}\end{array}$ & $\begin{array}{l}\text { Systolic: FeFol } \\
\text { + vit A, } \\
95.2 \mathrm{mmHg} \text {; } \\
\text { MMN, } \\
95.5 \mathrm{mmHg} ; \\
\text { calculated } \\
\text { difference, } \\
0.29 \mathrm{mmHg} \\
(95 \% \mathrm{Cl},-0.65 \\
\text { to } 1.23)^{d} \\
\text { Diastolic: FeFol } \\
\text { + vit A, } \\
63.9 \mathrm{mmHg} ; \\
\text { MMN, } \\
64.4 \mathrm{mmHg} ;\end{array}$ & $\begin{array}{l}\text { Non-fasting } \\
\text { glucose: FeFol + } \\
\text { vit A, } \\
3.91 \mathrm{mmol} / \mathrm{L} ; \\
\mathrm{MMN}, 3.86 \\
\mathrm{mmol} / \mathrm{L} ; \\
\mathrm{LDL} \text { : FeFol + } \\
\text { vit A, } \\
1.89 \mathrm{mmol} / \mathrm{L} ; \\
\mathrm{MMN}, 1.84 \\
\mathrm{mmol} / \mathrm{L} ; \mathrm{HDL} \text {; } \\
\text { FeFol + vit A, } \\
0.72 \mathrm{mmol} / \mathrm{L} ; \\
\mathrm{MMN}, 0.70 \\
\mathrm{mmol} / \mathrm{L} ; \text { at risk }\end{array}$ \\
\hline
\end{tabular}


Table 4 Anthropometry, body composition and cardiovascular results (Continued)

Results are unadjusted differences unless otherwise stated. Calculated differences use results given in the paper to calculate the difference (intervention - control) in outcome and confidence intervals $11.9 \%$

$H D L$ high density lipoprotein, $L D L$ low density lipoprotein, $\mathrm{FeFol}$ iron and folic acid, $M M N$ multiple micronutrient supplement

aComparisons were made with the $60 \mathrm{mg}$ iron, $400 \mu \mathrm{g}$ folic acid group and "usual" food supplementation

${ }^{b}$ Parity, gestation, age at measurement, age at delivery, malaria treatment, health centre

'Malaria, health centre, parity, gestational age

'Mixed linear models. Fixed effects: treatment, age, gender, birth weight, preterm, parity, feed methods, time of stay at outdoor, illness or health in last month before the interview, mother's height, educational level,

occupation, number of supplement tablets consumed, and family socioeconomic status; random effects: village and individual subject

'We have adjusted for cluster randomized controlled trial, assuming a design effect of 1.20 


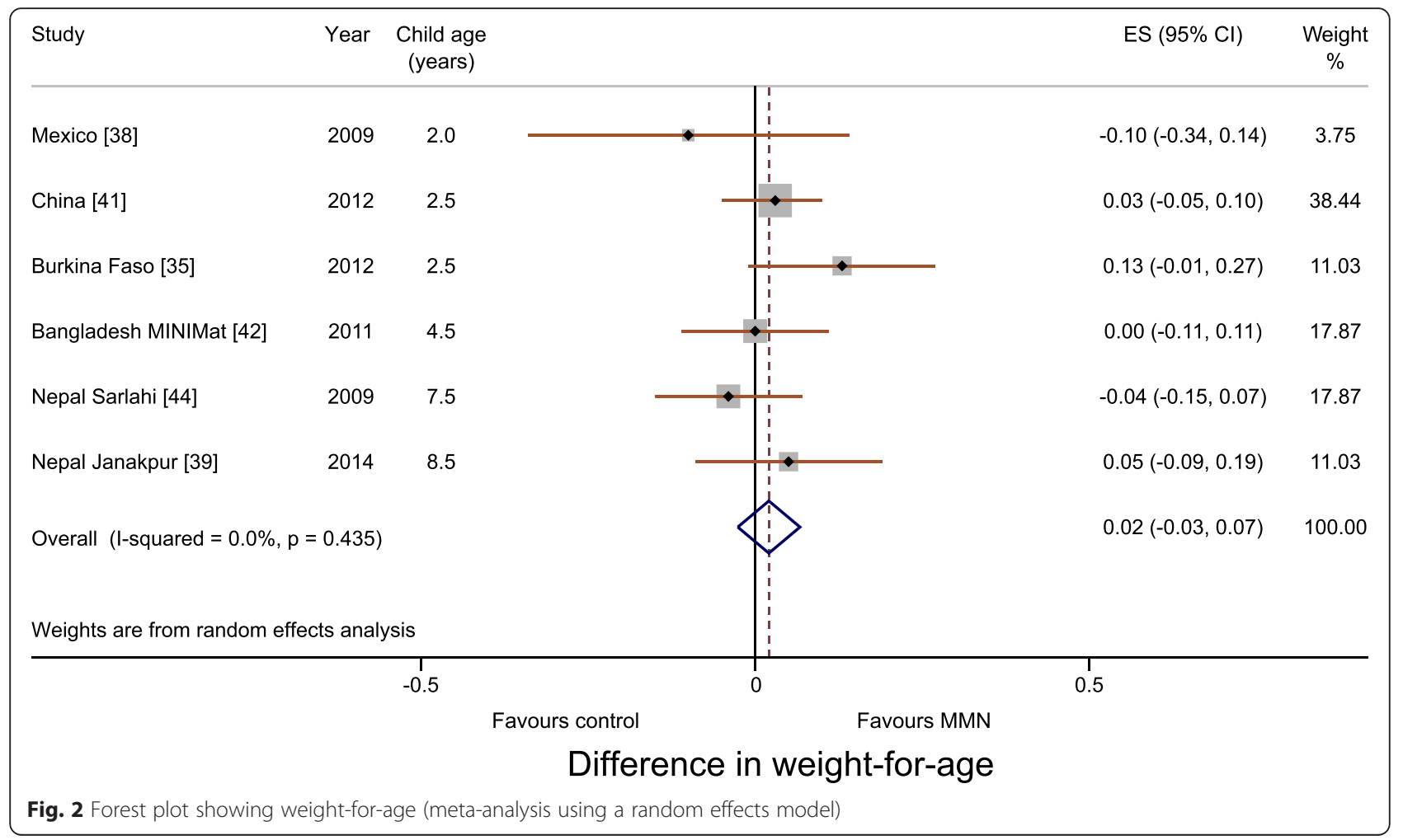

case of the Bangladesh JiVitA Indonesia trials) [29]. Follow-up reports described power or sample size calculations before data collection, with the exception of the Bangladesh MINIMat (cardiovascular) [46], Burkina Faso (anthropometry) [35] and Nepal Sarlahi (anthropometry and cardiovascular reports) follow-up publications [44, 47]. There was little statistical heterogeneity, with $\mathrm{I}^{2}$ values low for primary analyses (0-8\%). Some clinical heterogeneity was present as participants were from different countries and ages of follow-up varied. The intervention was the same in most cases, but (as described above) the Bangladesh JiVitA, Mexico and Nepal Sarlahi trials used slightly different multiple micronutrient formulations, and the Bangladesh JiVitA, Indonesia, Mexico and Nepal Sarlahi trials used different controls. Although choice of outcomes varied from one report to another, similar methods were used to assess similar outcomes.

\section{Selection bias}

Primarily a result of inadequate randomisation and allocation concealment, this has been covered in the 2015 Cochrane assessment [20]. An additional potential source of bias is selection of trials from the Cochrane review that did not show an increase in birthweight associated with MMN supplementation. The Cochrane review included 14 trials in its analysis of SGA. Of the five not considered here [56-60], one showed a significant reduction in SGA (Fawzi et al. [57], Tanzania; RR, 0.79; 95 \% CI, 0.70-0.89).
Supplement composition was substantially different in this trial, which compared a supplement containing eight vitamins and no minerals with a $60 \mathrm{mg}$ iron and $250 \mu \mathrm{g}$ folic acid control [57]. Meta-analysis of the trials included in our review showed an increase in birthweight of $30.2 \mathrm{~g}$ (95\% CI, 14.1 to 46.3 ), which is similar in magnitude to that found in previous meta-analyses [11, 61-63]. Similarly, three of the 11 trials included in the meta-analysis of neonatal mortality did not conduct follow-up studies. None of these trials showed a reduction in neonatal mortality. Meta-analysis of neonatal mortality rate for included trials produced an RR of 1.01 (95\% CI, 0.90 to 1.16).

\section{Performance and detection bias}

Participants and data collectors in all follow-up reports remained blind to allocation, with the exception of GuineaBissau, where this was not mentioned explicitly in the report.

\section{Attrition bias}

While all reports described loss to follow-up (Table 2), attrition bias was relatively small (0-29\%), except in the Mexico trial, in which just over half the children were seen at 24 months. The largest group lost were too old (>3 months) at the start of the follow-up. Excluding this group, follow-up rates were similar to those of the other reports. No important differences in loss to follow-up 


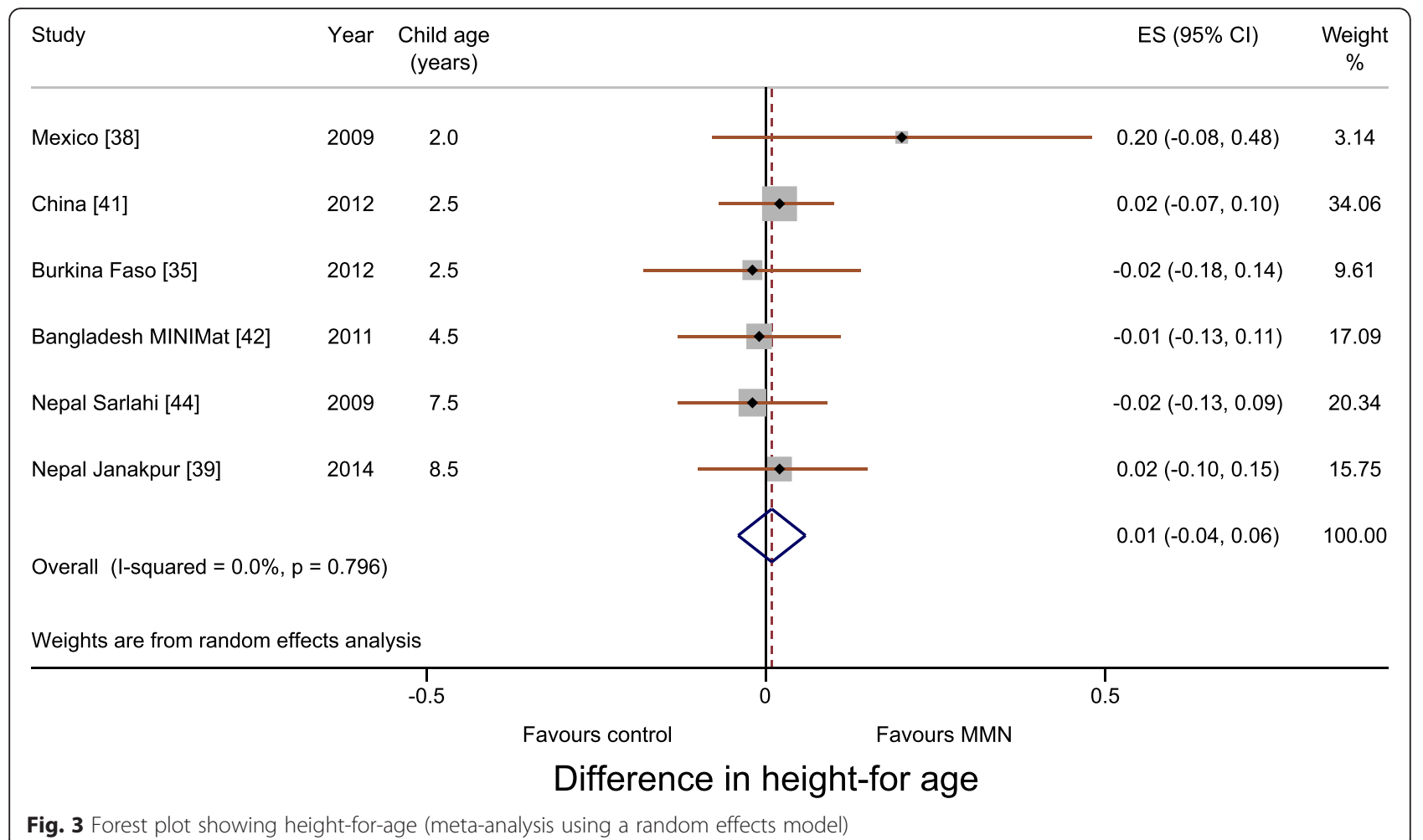

between allocation groups were reported, with the exception of China at 9 years, where study groups differed by school type, recent respiratory tract infection, mother's occupation (farmer or other) and father's level of education. These biases work in opposite directions and were accounted for in the analyses [50]. Where recorded, differences between children retained and lost to follow-up were small. Children lost to follow-up tended to have mothers with more education (Bangladesh MINIMat, Nepal Janakpur, Mexico and Nepal Sarlahi), lower parity and younger age (Bangladesh MINIMat and Mexico), and were more likely to live in an urban location (Nepal Janakpur), have differences in ethnicity and assets (Nepal Sarlahi), and lower birthweight and shorter gestation (Bangladesh MINIMat). Maternal age, weight, height and parity also differed in Guinea-Bissau, but the directions of these effects were not reported. Although most reports did not enumerate them, losses for individual outcomes also occurred: ( $>20 \%$ loss to measurement) kidney volume and function in the Bangladesh MINIMat trial, body composition in the Nepal Janakpur trial, and fasting glucose, insulin and homeostasis model assessment in the Nepal Sarlahi trial.

\section{Reporting bias}

We could not make a definitive assessment of reporting bias as follow-up protocols were unpublished, but funnel plots for mortality, HAZ, WAZ and head circumference, using results from the most recent follow-up report, did not suggest publication bias for the primary outcomes (Additional file 1: Figure S5).

\section{Discussion}

We found 20 follow-up reports for nine trials, covering a range of health outcomes. Nine studies reported on mortality, six on weight, six on height, and four on cognitive function, but there were few reports of other outcomes. Our hypothesis was not confirmed - we found no evidence that antenatal MMN supplementation, compared with iron and folic acid supplementation, led to improved survival, improved growth, lower blood pressure, or improved lung function in childhood. Potential improvements in cognitive outcomes were observed, but these were small and inconsistent and tended to be seen in subgroups.

\section{Quality of trials and limitations of the review}

The trials had low risks of bias and were generally considered of high-quality [20]. The degree of loss to follow-up was not substantial, although in some cases only subgroups were followed up. Differential loss to follow-up between intervention and control groups did not appear to be an issue, and neither did selective publication, as most trials reported null findings. The evidence on antenatal MMN supplementation comes from a large sample and a substantial number of trials, 


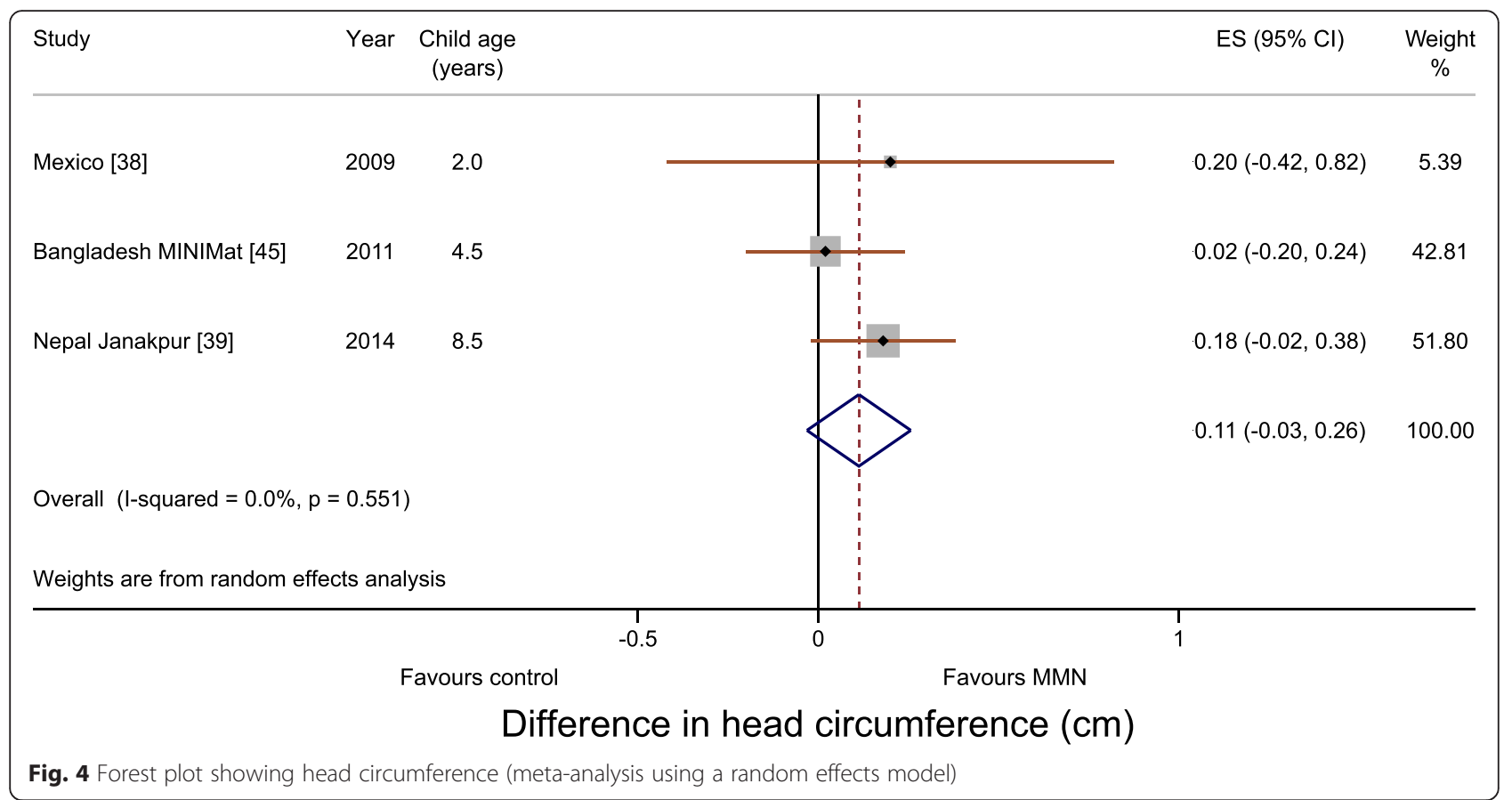

many of which were coordinated. The trials considered here were spread geographically, although 13 of the 20 follow-up reports were from South Asia, which may have affected generalizability. Differences between the Nepal and Bangladesh reports emphasize the fact that variation can occur within similar populations.

The main limitation was that not all trials had published reports on follow-up. We cannot be certain whether a selection bias exists, but we found no indication of this. Follow-up reports have published null findings, rather than positive ones. If a publication bias does exist, it would not work in this direction. None of the trials had initially set out to observe childhood outcomes. While power calculations were performed prior to most follow-ups, trials were powered on birth outcomes and larger sample sizes may be required to detect small differences in childhood. Functional outcomes were measured at different ages and may not be comparable. We attempted to address this by using $z$ scores, adjusted for age and sex, as primary outcomes. This was not always possible and limits inferences from the head circumference and blood pressure findings. We tried to make comparisons as similar as possible, but our findings could be vitiated by slightly different MMN and control supplement compositions in some trials.

\section{Mortality}

Antenatal MMN supplementation was initially hypothesized to reduce mortality, but increases in neonatal mortality were suspected in some trials [64]. A meta-analysis did not find a difference in neonatal mortality overall, but raised concerns about increased early neonatal mortality (OR, 1.23; $95 \%$ CI, 0.95 to 1.59 ). The 2015 Cochrane review found a reduction in stillbirths (0.91; $95 \% \mathrm{CI}, 0.85$ to $0.98, n=15$ ), and no effect on perinatal $(0.97 ; 95 \% \mathrm{CI}, 0.84$ to $1.12, n=12)$ or neonatal mortality (0.98; $95 \% \mathrm{CI}, 0.90$ to $1.07, n=11)$ [20]. The reduction in stillbirths is interesting and potentially important [65]. It depended on the analytical weighting (57\%) of the study by West et al. [26] and the use of a fixed effects model, and requires confirmation. A suggestion that MMN supplementation would prevent 43,715 annual child deaths (with $90 \%$ coverage in 34 countries most in need) followed from the Lives Saved Tool model, based on evidence that reductions in the prevalence of SGA are associated with reduced stunting and subsequent child survival [12]. Our analyses did not identify evidence of an effect on child mortality and do not support the assumptions made in the Lives Saved Tool.

\section{Anthropometry and body composition}

Overall, follow-up reports did not show differences in anthropometry or body composition. A transient improvement was seen in early life in the Burkina Faso and Nepal Janakpur trials, and there was a suggestion of increased stunting in Bangladesh, but these findings were not replicated in other reports. There was a consistent lack of effect on height. It is conceivable that MMN supplementation could have physiological effects that are not manifest in substantial anthropometric change. For example, transient greater weight in early childhood could have long-term benefits, even if not apparent in the short-term. 


\section{Cognitive development}

Small improvements in mental development were seen in China [49] at 1 year but not at 9 years, cognitive score was lower in Nepal Sarlahi [51], and the Bangladesh MINIMat and Indonesia trials found improvements in subgroups of mothers with poorer nutritional status only $[37,48]$. Considering the number and range of tests conducted, antenatal MMN supplements did not appear to lead to a consistent cognitive benefit. When found, differences tended to be small and three of the five reports involved children under 4 years, in whom cognitive tests are less reliable than in older children. Further assessment of these cohorts is warranted.

\section{Other outcomes}

Comparison of follow-ups did not confirm the impression of transiently lower systolic blood pressure at 2.5 years in the Nepal Janakpur trial, or of improved lung function in children seen in a similar trial of vitamin A supplementation from Nepal Sarlahi [66]. Only one trial considered other cardiovascular risk markers and found no effects.

\section{Inferences}

On the basis of the reports we have reviewed, current evidence does not support changing the recommendation for routine antenatal supplementation from iron and folic acid to MMN formulations. It is possible even probable - that the trial populations differed in their patterns of micronutrient deficiency. There was little evidence to suggest that this influenced the general findings. Although there is consistent evidence that antenatal MMN supplementation increases birth weight, none of the studies demonstrated convincingly that it benefitted offspring in terms of functional or health outcomes, and the directions and magnitudes of effect were similar for mortality and anthropometric outcomes across the study sites. The findings of the Cochrane review on which recent advocacy for routine antenatal MMN supplementation are based are supported by other meta-analyses that have shown an increase in mean birthweight of 22-54 g and corresponding reductions in low birthweight and SGA. As may be expected, the erosion over time of anthropometric differences observed at birth suggests that infants of women who received antenatal MMN supplements lost an advantage over the first few years. This could be the result of numerous environmental stresses over postnatal life. No other changes in anthropometry, gestation or mortality were found $[11,20,22$, 61-63]. However, improvement in later health outcomes does not necessarily depend on supplementation causing an increase in birthweight (or organ size). The mechanisms of action are likely to be multifactorial and followup reports suggest other mechanisms such as the effect of vitamin A on regulation of fetal lung growth, branching and alveolarisation $[67,68]$. We also cannot rule out effects emerging later in life or in the next generation. From an evolutionary perspective, supplementing mothers could potentially benefit the woman herself, the index baby, or future offspring. Antenatal micronutrient supplementation has a role in women with a deficiency-related illness, and possibly in micronutrient deficiency itself, but population supplementation may need to start earlier, either in the first trimester or pre-conception, to include the period of rapid organogenesis and genome-wide epigenetic changes that follow fertilization, and be continued into childhood $[16,69,70]$. The formulations of MMN tested may also not be the optimum ones. We cannot rule out the possibility that combinations other than the ones tested might have positive outcomes. It is possible that additional micronutrients, or different doses, might result in functional benefits.

The annual cost of MMN supplementation in pregnancy (at $90 \%$ coverage) in the 34 LMICs in which it would be most useful is estimated at (International)\$ 472 million [12]. If, as our review suggests, initiating antenatal MMN supplementation in early/mid-pregnancy does not lead to the anticipated improvements in childhood function or health - the main current justification for recommending it - the opportunity costs to other programmes that do lead to improvements will need to be considered.

\section{Implications for future research}

More evidence is needed, especially on cognitive development, cardiovascular risk markers and lung function, to adequately appraise the long-term effects of antenatal MMN supplementation. We recommend follow-up studies in more of the MMN trials. Further research into biological mechanisms by which an early advantage could be attenuated will help in our understanding of the intervention and in designing future trials.

\section{Conclusions}

In summary, our review of published follow-up reports has not shown persisting effects of antenatal MMN supplementation during childhood, compared with iron and folic acid. Phenotypic and physiological differences may arise later in life or as more research is conducted, but the current evidence base is insufficient to support routine MMN supplementation in pregnancy at a population level in low- and middle-income countries.

\section{Additional file}

Additional file 1: The search strategy, micronutrient constituents, PRISMA flow chart, sub-group analyses and funnel plots. (PDF 305 kb)

\section{Abbreviations}

BMI, body mass index; HAZ, height-for-age z score; MMN, multiple micronutrient; SGA, small for gestational age; WAZ, weight-for-age z score; WHO, World Health Organization 


\section{Acknowledgements}

Heather Chesters helped perform the literature search.

\section{Funding}

There was no specific funding for this study. DD is supported by the National Institute of Health Research. DO is supported by The Wellcome Trust (091561/Z/10/Z). HSS receives support from Sitaram Bhartia Institute of Science and Research, New Delhi. CHDF and CO are supported by the Medical Research Council and Department for International Development.

\section{Authors' contributions}

DD and JCKW performed the literature search. AC, BM, CHDF, DD, DO, HSS, and JCKW reviewed the reports and extracted the data. DD and $C O$ performed the analysis. DD wrote the first draft. All authors read and criticised drafts of the manuscript.

\section{Competing interests}

The authors declare that they have no competing interests.

\section{Consent for publication}

There is no individual person data.

\section{Ethics approval and consent to participate}

Not applicable. The paper is a review of published research and there was no primary data collection.

\section{Author details}

${ }^{1}$ Institute for Global Health, University College London, 30 Guilford St, London, UK. ${ }^{2}$ MRC Lifecourse Epidemiology Unit, University of Southampton, Southampton General Hospital, Tremona Road, Southampton, UK. ${ }^{3}$ Pediatrics and Clinical Epidemiology at Sitaram Bhartia Institute of Science and Research, B-16, Qutab Institutional Area, New Delhi, India. ${ }^{4}$ Faculty of Medicine, University of Southampton, Southampton General Hospital, Tremona Road, Southampton, UK. ${ }^{5}$ Childhood Nutrition Research Centre, Institute of Child Health, University College London, 30 Guilford St, London, UK.

Received: 11 February 2016 Accepted: 2 June 2016 Published online: 16 June 2016

\section{References}

1. Micronutrient deficiencies. http://www.who.int/nutrition/.

2. Fall CH, Yajnik CS, Rao S, Davies AA, Brown N, Farrant HJ. Micronutrients and fetal growth. J Nutr. 2003;133(5 Suppl 2):1747S-56.

3. Christian P, Stewart CP. Maternal micronutrient deficiency, fetal development, and the risk of chronic disease. J Nutr. 2010;140(3):437-45.

4. Costello AM, Osrin D. Micronutrient status during pregnancy and outcomes for newborn infants in developing countries. J Nutr. 2003;133(5 Suppl 2): 1757S-64.

5. Stevens GA, Finucane MM, De-Regil LM, Paciorek CJ, Flaxman SR, Branca F, et al. Global, regional, and national trends in haemoglobin concentration and prevalence of total and severe anaemia in children and pregnant and non-pregnant women for 1995-2011: a systematic analysis of populationrepresentative data. Lancet Glob Health. 2013;1(1):e16-25.

6. World Health Organisation. Global prevalence of vitamin A deficiency in populations at risk 1995-2005. WHO Global Database on Vitamin A Deficiency. Geneva: World Health Organization; 2009.

7. McCauley ME, van den Broek N, Dou L, Othman M. Vitamin A supplementation during pregnancy for maternal and newborn outcomes. Cochrane Database Syst Rev. 2015;10:CD008666.

8. De-Regil LM, Fernandez-Gaxiola AC, Dowswell T, Pena-Rosas JP. Effects and safety of periconceptional folate supplementation for preventing birth defects. Cochrane Database Syst Rev. 2010;10:CD007950.

9. Blencowe $\mathrm{H}$, Cousens $\mathrm{S}$, Modell B, Lawn J. Folic acid to reduce neonatal mortality from neural tube disorders. Int J Epidemiol. 2010;39 Suppl 1:11 10-21.

10. Pena-Rosas JP, De-Regil LM, Dowswell T, Viteri FE. Daily oral iron supplementation during pregnancy. Cochrane Database Syst Rev. 2012;12:CD004736.

11. Fall CH, Fisher DJ, Osmond C, Margetts BM. Multiple micronutrient supplementation during pregnancy in low-income countries: a metaanalysis of effects on birth size and length of gestation. Food Nutr Bull. 2009;30(4 Suppl):S533-46.
12. Bhutta ZA, Das JK, Rizvi A, Gaffey MF, Walker N, Horton S, et al. Evidencebased interventions for improvement of maternal and child nutrition: what can be done and at what cost? Lancet. 2013;382(9890):452-77.

13. Haider BA, Bhutta ZA. Multiple-micronutrient supplementation for women during pregnancy. Cochrane Database Syst Rev. 2012;11:CD004905.

14. Victora CG, Adair L, Fall C, Hallal PC, Martorell R, Richter L, et al. Maternal and child undernutrition: consequences for adult health and human capital. Lancet. 2008;371(9609):340-57.

15. Barker DJ, Gluckman PD, Godfrey KM, Harding JE, Owens JA, Robinson JS. Fetal nutrition and cardiovascular disease in adult life. Lancet. 1993: 341(8850):938-41.

16. Waterland RA, Michels KB. Epigenetic epidemiology of the developmental origins hypothesis. Annu Rev Nutr. 2007;27:363-88.

17. Barker DJ. Fetal origins of coronary heart disease. BMJ. 1995;311(6998):171-4.

18. Painter RC, Roseboom TJ, Bleker OP. Prenatal exposure to the Dutch famine and disease in later life: an overview. Reprod Toxicol. 2005;20(3):345-52.

19. Warner MJ, Ozanne SE. Mechanisms involved in the developmental programming of adulthood disease. Biochem J. 2010;427:333-47.

20. Haider BA, Bhutta ZA. Multiple-micronutrient supplementation for women during pregnancy. Cochrane Database Syst Rev. 2015;11:CD004905.

21. World Health Organization. Guideline: daily iron and folic acid supplementation in pregnant women. Geneva: World Health Organization; 2012.

22. Ronsmans C, Fisher DJ, Osmond C, Margetts BM, Fall CH. Maternal Micronutrient Supplementation Study Group. Multiple micronutrient supplementation during pregnancy in low-income countries: a metaanalysis of effects on stillbirths and on early and late neonatal mortality. Food Nutr Bull. 2009;30(4 Suppl):S547-55.

23. Roberfroid D, Huybregts L, Lanou H, Henry MC, Meda N, Menten J, et al. Effects of maternal multiple micronutrient supplementation on fetal growth: a double-blind randomized controlled trial in rural Burkina Faso. Am J Clin Nutr. 2008;88(5):1330-40

24. Kaestel $P$, Michaelsen KF, Aaby P, Friis H. Effects of prenatal multimicronutrient supplements on birth weight and perinatal mortality: a randomised, controlled trial in Guinea-Bissau. Eur J Clin Nutr. 2005;59(9):1081-9.

25. Ramakrishnan U, Gonzalez-Cossio T, Neufeld LM, Rivera J, Martorell R. Multiple micronutrient supplementation during pregnancy does not lead to greater infant birth size than does iron-only supplementation: a randomized controlled trial in a semirural community in Mexico. Am J Clin Nutr. 2003:77(3):720-5.

26. West Jr KP, Shamim AA, Mehra S, Labrique AB, Ali H, Shaikh S, et al. Effect of maternal multiple micronutrient vs iron-folic acid supplementation on infant mortality and adverse birth outcomes in rural Bangladesh: the JiVitA-3 randomized trial. JAMA. 2014:312(24):2649-58.

27. Persson LA, Arifeen S, Ekstrom EC, Rasmussen KM, Frongillo EA, Yunus M, et al. Effects of prenatal micronutrient and early food supplementation on maternal hemoglobin, birth weight, and infant mortality among children in Bangladesh: the MINIMat randomized trial. JAMA. 2012;307(19):2050-9.

28. Zeng L, Dibley MJ, Cheng Y, Dang S, Chang S, Kong L, et al. Impact of micronutrient supplementation during pregnancy on birth weight, duration of gestation, and perinatal mortality in rural western China: double blind cluster randomised controlled trial. BMJ. 2008;337:a2001.

29. Supplementation with Multiple Micronutrients Intervention Trial Study Group, Shankar AH, Jahari AB, Sebayang SK, Aditiawarman, Apriatni M, et al. Effect of maternal multiple micronutrient supplementation on fetal loss and infant death in Indonesia: a double-blind cluster-randomised trial. Lancet. 2008:371(9608):215-27.

30. Osrin D, Vaidya A, Shrestha Y, Baniya RB, Manandhar DS, Adhikari RK, et al. Effects of antenatal multiple micronutrient supplementation on birthweight and gestational duration in Nepal: double-blind, randomised controlled trial. Lancet. 2005;365(9463):955-62.

31. Christian P, West KP, Khatry SK, Leclerq SC, Pradhan EK, Katz J, et al. Effects of maternal micronutrient supplementation on fetal loss and infant mortality: a cluster-randomized trial in Nepal. Am J Clin Nutr. 2003;78(6): 1194-202.

32. Margetts $\mathrm{BM}$, Fall $\mathrm{CH}$, Ronsmans $\mathrm{C}$, Allen LH, Fisher DJ. Maternal Micronutrient Supplementation Study Group. Multiple micronutrient supplementation during pregnancy in low-income countries: review of methods and characteristics of studies included in the meta-analyses. Food Nutr Bull. 2009:30(4 Suppl):S517-26.

33. UNICEF/WHO/UN. Composition of a multi-micronutrient supplement to be used in pilot programmes among pregnant women in developing countries. New York: United Nations Children's Fund; 1999. 
34. Christian P, Khatry SK, Katz J, Pradhan EK, LeClerq SC, Shrestha SR, et al. Effects of alternative maternal micronutrient supplements on low birth weight in rural Nepal: double blind randomised community trial. BMJ. 2003;326(7389):571.

35. Roberfroid D, Huybregts L, Lanou H, Ouedraogo L, Henry MC, Meda N, et al. Impact of prenatal multiple micronutrients on survival and growth during infancy: a randomized controlled trial. Am J Clin Nutr. 2012;95(4):916-24.

36. Andersen GS, Friis H, Michaelsen KF, Rodrigues A, Benn CS, Aaby P, et al. Effects of maternal micronutrient supplementation on fetal loss and under2-years child mortality: long-term follow-up of a randomised controlled trial from Guinea-Bissau. Afr J Reprod Health. 2010;14(2):17-26.

37. Prado EL, Alcock KJ, Muadz H, Ullman MT, Shankar AH, Group SS. Maternal multiple micronutrient supplements and child cognition: a randomized trial in Indonesia. Pediatrics. 2012;130(3):e536-46.

38. Ramakrishnan U, Neufeld LM, Flores R, Rivera J, Martorell R. Multiple micronutrient supplementation during early childhood increases child size at 2 y of age only among high compliers. Am J Clin Nutr. 2009;89(4):1125-31.

39. Devakumar D, Chaube SS, Wells JCK, Saville NM, Ayres JG, Manandhar DS, et al. Effect of antenatal multiple micronutrient supplementation on anthropometry and blood pressure in mid-childhood in Nepal: follow-up of a double-blind randomised controlled trial. Lancet Glob Health. 2014;2(11):e654-63.

40. Christian P, Stewart CP, LeClerq SC, Wu L, Katz J, West KP, et al. Antenatal and postnatal iron supplementation and childhood mortality in rural Nepal: a prospective follow-up in a randomized, controlled community trial. Am J Epidemiol. 2009;170(9):1127-36.

41. Wang W, Yan H, Zeng L, Cheng Y, Wang D, Li Q. No effect of maternal micronutrient supplementation on early childhood growth in rural western China: 30 month follow-up evaluation of a double blind, cluster randomized controlled trial. Eur J Clin Nutr. 2012;66(2):261-8.

42. Khan Al, Kabir I, Ekstrom EC, Asling-Monemi K, Alam DS, Frongillo EA, et al. Effects of prenatal food and micronutrient supplementation on child growth from birth to 54 months of age: a randomized trial in Bangladesh. Nutr J. 2011:10:134.

43. Vaidya A, Saville N, Shrestha BP, Costello AM, Manandhar DS, Osrin D. Effects of antenatal multiple micronutrient supplementation on children's weight and size at 2 years of age in Nepal: follow-up of a double-blind randomised controlled trial. Lancet. 2008:371(9611):492-9.

44. Stewart CP, Christian P, LeClerq SC, West Jr KP, Khatry SK. Antenatal supplementation with folic acid + iron + zinc improves linear growth and reduces peripheral adiposity in school-age children in rural Nepal. Am J Clin Nutr. 2009;90(1):132-40

45. Khan Al, Kabir I, Hawkesworth S, Ekstrom EC, Arifeen S, Frongillo EA, et al. Early invitation to food and/or multiple micronutrient supplementation in pregnancy does not affect body composition in offspring at 54 months: follow-up of the MINIMat randomised trial. Bangladesh Matern Child Nutr. 2015;11(3):385-97.

46. Hawkesworth S, Wagatsuma Y, Kahn Al, Hawlader MD, Fulford AJ, Arifeen SE, et al. Combined food and micronutrient supplements during pregnancy have limited impact on child blood pressure and kidney function in rural Bangladesh. J Nutr. 2013;143(5):728-34.

47. Stewart CP, Christian P, Schulze KJ, Leclerq SC, West Jr KP, Khatry SK. Antenatal micronutrient supplementation reduces metabolic syndrome in 6- to 8-year-old children in rural Nepal. J Nutr. 2009;139(8):1575-81.

48. Tofail F, Persson LA, El Arifeen S, Hamadani JD, Mehrin F, Ridout D, et al. Effects of prenatal food and micronutrient supplementation on infant development: a randomized trial from the Maternal and Infant Nutrition Interventions, Matlab (MINIMat) study. Am J Clin Nutr. 2008;87(3):704-11.

49. Li Q, Yan H, Zeng L, Cheng Y, Liang W, Dang S, et al. Effects of maternal multimicronutrient supplementation on the mental development of infants in rural western China: follow-up evaluation of a double-blind, randomized, controlled trial. Pediatrics. 2009;123(4):e685-92.

50. Li C, Zeng L, Wang D, Yang W, Dang S, Zhou J, et al. Prenatal micronutrient supplementation is not associated with intellectual development of young school-aged children. J Nutr. 2015;145(8):1844-9.

51. Christian P, Murray-Kolb LE, Khatry SK, Katz J, Schaefer BA, Cole PM, et al Prenatal micronutrient supplementation and intellectual and motor function in early school-aged children in Nepal. JAMA. 2010;304(24):2716-23.

52. Devakumar D, Stocks J, Ayres JG, Kirkby J, Yadav SK, Saville NM, et al. Effects of antenatal multiple micronutrient supplementation on lung function in mid- childhood: follow-up of a double-blind randomised controlled trial in Nepal. Eur Resp J. 2015;45(6):1566-75.
53. Khan Al, Hawkesworth S, Hawlader MD, El Arifeen S, Moore S, Hills AP, et al. Body composition of Bangladeshi children: comparison and development of leg-to-leg bioelectrical impedance equation. J Health Popul Nutr. 2012; 30(3):281-90.

54. Devakumar D, Grijalva-Eternod CS, Roberts S, Chaube SS, Saville NM, Manandhar DS, et al. Body composition in Nepalese children using isotope dilution: the production of ethnic-specific calibration equations and an exploration of methodological issues. Peer J. 2015;3:e785.

55. Miller MR, Hankinson J, Brusasco V, Burgos F, Casaburi R, Coates A, et al. Standardisation of spirometry. Eur Respir J. 2005;26(2):319-38.

56. Bhutta ZA, Rizvi A, Raza F, Hotwani S, Zaidi S, Moazzam Hossain S, et al. A comparative evaluation of multiple micronutrient and iron-folic acid supplementation during pregnancy in Pakistan: impact on pregnancy outcomes. Food Nutr Bull. 2009;30(4 Suppl):S496-505.

57. Fawzi WW, Msamanga Gl, Urassa W, Hertzmark E, Petraro P, Willett WC, et al. Vitamins and perinatal outcomes among HIV-negative women in Tanzania. New Engl J Med. 2007;356(14):1423-31.

58. Friis H, Gomo E, Nyazema N, Ndhlovu P, Krarup H, Kaestel $P$, et al. Effect of multimicronutrient supplementation on gestational length and birth size: a randomized, placebo-controlled, double-blind effectiveness trial in Zimbabwe. Am J Clin Nutr. 2004;80(1):178-84.

59. Sunawang, Utomo B, Hidayat A, Kusharisupeni, Subarkah. Preventing low birthweight through maternal multiple micronutrient supplementation: a cluster-randomized, controlled trial in Indramayu, West Java. Food Nutr Bull. 2009;30(4 Suppl):S488-495

60. Zagre NM, Desplats G, Adou P, Mamadoultaibou A, Aguayo VM. Prenatal multiple micronutrient supplementation has greater impact on birthweight than supplementation with iron and folic acid: a cluster-randomized, double-blind, controlled programmatic study in rural Niger. Food Nutr Bull. 2007;28(3):317-27

61. Shah PS, Ohlsson A, Knowledge Synthesis Group on Determinants of Low Birth Weight Preterm Births. Effects of prenatal multimicronutrient supplementation on pregnancy outcomes: a meta-analysis. CMAJ. 2009;180(12):E99-108.

62. Kawai K, Spiegelman D, Shankar AH, Fawzi WW. Maternal multiple micronutrient supplementation and pregnancy outcomes in developing countries: meta-analysis and meta-regression. Bull World Health Organ. 2011:89(6):402-411B.

63. Ramakrishnan U, Grant FK, Goldenberg T, Bui V, Imdad A, Bhutta ZA. Effect of multiple micronutrient supplementation on pregnancy and infant outcomes: a systematic review. Paediatr Perinat Epidemiol. 2012;26 Suppl 1:153-67.

64. Christian P, Osrin D, Manandhar DS, Khatry SK, de L Costello AM, West Jr KP. Antenatal micronutrient supplements in Nepal. Lancet. 2005;366(9487):711-2

65. Lawn JE, Blencowe H, Pattinson R, Cousens S, Kumar R, Ibiebele I, et al. Stillbirths: Where? When? Why? How to make the data count? Lancet. 2011; 377(9775):1448-63.

66. Checkley W, West Jr KP, Wise RA, Baldwin MR, Wu L, LeClerq SC, et al. Maternal vitamin A supplementation and lung function in offspring. N Engl J Med. 2010:362(19):1784-94.

67. Wellik DM, Norback DH, DeLuca HF. Retinol is specifically required during midgestation for neonatal survival. Am J Physiol. 1997;272(1 Pt 1):E25-9.

68. Pinto Mde L, Rodrigues P, Coelho AC, Pires Mdos A, dos Santos DL, Goncalves $C$, et al. Prenatal administration of vitamin A alters pulmonary and plasma levels of vascular endothelial growth factor in the developing mouse. Int J Exper Pathol. 2007;88(6):393-401.

69. Nafee TM, Farrell WE, Carroll WD, Fryer AA, Ismail KM. Epigenetic control of fetal gene expression. BJOG. 2008;115(2):158-68.

70. Khulan B, Cooper WN, Skinner BM, Bauer J, Owens S, Prentice AM, et al. Periconceptional maternal micronutrient supplementation is associated with widespread gender related changes in the epigenome: a study of a unique resource in the Gambia. Hum Mol Genet. 2012;21(9):2086-101. 